\title{
Effect of melting Antarctic sea ice on the fate of microbial communities studied in microcosms
}

\author{
D. Lannuzel • V. Schoemann - I. Dumont • \\ M. Content $\cdot$ J. de Jong $\cdot$ J.-L. Tison · \\ B. Delille $\cdot S$. Becquevort
}

Received: 19 December 2012/Revised: 13 June 2013 / Accepted: 28 June 2013 / Published online: 12 July 2013

(C) The Author(s) 2013. This article is published with open access at Springerlink.com

\begin{abstract}
Although algal growth in the iron-deficient Southern Ocean surface waters is generally low, there is considerable evidence that winter sea ice contains high amounts of iron and organic matter leading to ice-edge blooms during austral spring. We used field observations and shipbased microcosm experiments to study the effect of the seeding by sea ice microorganisms, and the fertilization by organic matter and iron on the planktonic community at the onset of spring/summer in the Weddell Sea. Pack ice was a major source of autotrophs resulting in a ninefold to 27 -fold increase in the sea ice-fertilized seawater microcosm compared to the ice-free seawater microcosm. However, heterotrophs were released in lower numbers (only a 2- to 6-fold increase). Pack ice was also an important source of dissolved organic matter for the planktonic community. Small algae $(<10 \mu \mathrm{m})$ and bacteria released from melting sea ice were able to thrive in seawater. Field observations show that the supply
\end{abstract}

D. Lannuzel $(\bowtie)$

Institute for Marine and Antarctic Studies,

University of Tasmania, Locked Bag 129,

Hobart, TAS 7001, Australia

e-mail: delphine.lannuzel@utas.edu.au

D. Lannuzel

Antarctic Climate and Ecosystems CRC,

University of Tasmania, Private Bag 80,

Hobart, TAS 7001, Australia

D. Lannuzel

Laboratoire d'Océanographie Chimique et Géochimie des Eaux, Université Libre de Bruxelles, Campus de la Plaine CP208, Bd. du Triomphe, 1050 Bruxelles, Belgium

V. Schoemann $\cdot$ S. Becquevort

Ecologie des Systèmes Aquatiques, Faculté des Sciences, Université Libre de Bruxelles, Campus de la Plaine CP 221, Bd. du Triomphe, 1050 Bruxelles, Belgium of iron from melting sea ice had occurred well before our arrival onsite, and the supply of iron to the microcosms was therefore low. We finally ran a "sequential melting" experiment to monitor the release of ice constituents in seawater. Brine drainage occurred first and was associated with the release of dissolved elements (salts, dissolved organic carbon and dissolved iron). Particulate organic carbon and particulate iron were released with low-salinity waters at a later stage.

Keywords Sea ice - Microbial community . Antarctica $\cdot$ Iron

\section{Introduction}

It is now well established that iron (Fe) supply and availability is of critical importance for phytoplankton growth in

V. Schoemann · J. de Jong $\cdot$ J.-L. Tison

Laboratoire de Glaciologie (GLACIOL), Département des

Sciences de la Terre et de l'Environnement (DSTE), Faculté des

Sciences, Université Libre de Bruxelles, CP 160/03,

50 Av. F. D. Roosevelt, 1050 Brussels, Belgium

I. Dumont $\cdot$ M. Content $\cdot$ J. de Jong

Unité Isotopes Pétrologie et Environnement (IPE), Département des Sciences de la Terre et de l'Environnement (DSTE), Faculté des Sciences, Université Libre de Bruxelles, CP 160/02,

Avenue F.D. Roosevelt 50, 1050 Brussels, Belgium

B. Delille

Unité d'Océanographie Chimique, MARE, Université de Liège, Allée du 6 Août, 17, 4000 Liège, Belgium 
the high nutrient low chlorophyll (HNLC) Southern Ocean, where macro-nutrients levels are high but primary productivity remains low throughout the year due to widespread Fe limitation (Martin et al. 1990). There is evidence that sea ice is enriched in $\mathrm{Fe}$ and triggers ice-edge blooms when it melts in spring (Sedwick and DiTullio 1997; Lannuzel et al. 2010). Besides its role in storing Fe, sea ice can incorporate microorganisms (e.g. Gradinger and Ikävalko 1998; Rozanska et al. 2008), as well as organic matter (Thomas and Papadimitriou 2003; Becquevort et al. 2009) when it forms. Organisms trapped in sea ice can survive the extremely harsh winter conditions (restricted space to grow, low temperature and high salinity). When environmental conditions become favourable (light, temperature, salinity and nutrients), a large biomass of microorganisms then develop within the ice. When sea ice melts, these microorganisms, as well as organic and inorganic material (DOM and Fe), are released into a shallow and vertically stabilized water layer. This seasonal phenomenon produces ice-edge phytoplankton blooms visible on satellite pictures (Smith and Nelson 1986; Lancelot et al. 1993; Lancelot et al. 2009). The magnitude and duration of these blooms may vary widely in space and time (Arrigo et al. 2010 and references therein).

A small body of papers report laboratory experiments setup to understand the mechanisms controlling ice-edge plankton blooms (Mathot et al. 1991; Riebesell et al. 1991; Kuosa et al. 1992; Giesenhagen et al. 1999). These experiments mainly focussed on the Atlantic sector of the Southern Ocean and the Weddell Sea. In each of these studies, the experimental protocols were tailored to address specific questions; Mathot et al. (1991) simulated the seeding of sea ice algae in filtered seawater and provided information on the potential photosynthetic activity and growth of the sea ice algae released in a planktonic environment. Riebesell et al. (1991) assessed the aggregation potential of ice algae using rolling tanks. Kuosa et al. (1992) performed aquarium experiments involving addition of unfiltered brown ice/ slush into seawater to study the impact of sea ice microorganisms on the pelagic system. Similarly, Giesenhagen et al. (1999) ran microcosm experiments to separate the effects of the supply of organic matter from the effects of the supply of microorganisms on the microbial community and further investigated the loss of organic matter by sedimentation and/ or grazing by copepods. However, none of these studies were conducted under trace-metal clean conditions, which limits our understanding of the role of $\mathrm{Fe}$ in the sea ice realm. In addition, none of the above mentioned studies investigated the sequence with which the nutritive elements (organic matter and $\mathrm{Fe}$ ) and the microorganisms are released into seawater when sea ice melts.

This paper presents results from field observations during a time series and laboratory-based experiments

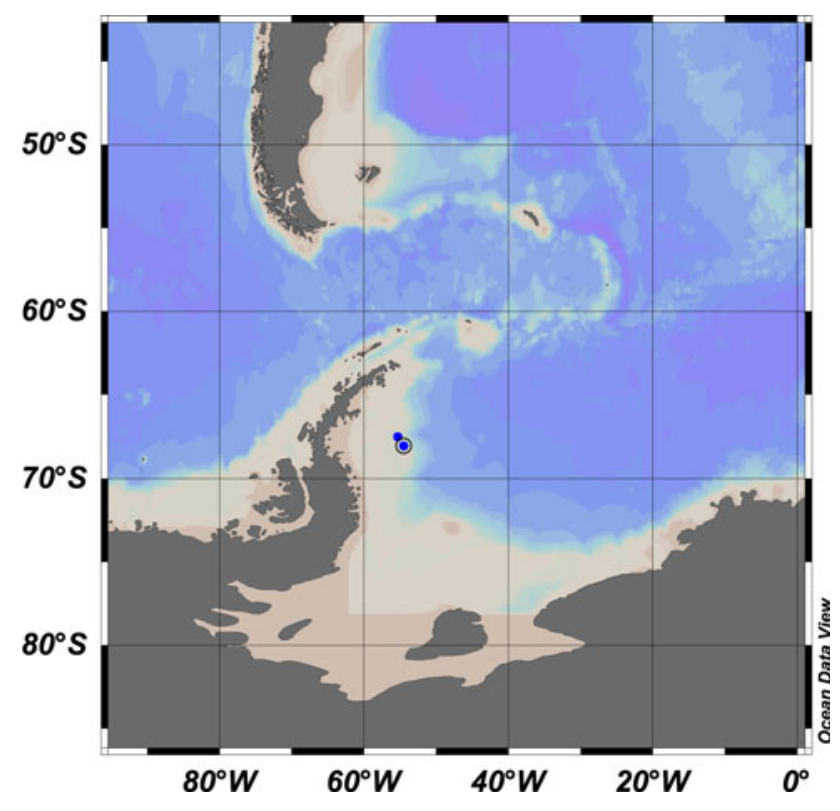

Fig. 1 Map of the sampling area (Schlitzer 2008). The blue dots mark the initial and final location of the ice floe

performed under trace-metal clean conditions, using sea ice and seawater collected during the 2004/2005 Ice Station POLarstern (ISPOL) research cruise in the Western Weddell Sea, Antarctica. First, an overview of the seasonal distribution of microorganisms, organic matter and $\mathrm{Fe}$ in $1^{\text {st }}$ year pack ice is given. Then, results from microcosm experiments performed onboard to investigate the effect of microorganisms, organic matter and $\mathrm{Fe}$ released from sea ice on microbial communities at two different times of the spring-summer season are presented. A final and complementary experiment was conducted in the home laboratory to study the sequence of release of each of these constituents from melting sea ice into seawater.

\section{Materials and methods}

\section{Field sampling}

Samples were collected in the pack ice zone during the ISPOL research cruise onboard the RV Polarstern in the Western Weddell Sea, Antarctic Peninsula $\left(68^{\circ} \mathrm{S} / 55^{\circ} \mathrm{W}\right.$, Fig. 1) in November-December 2004. The RV Polarstern was anchored to a large ice floe (few $\mathrm{km}$ in size) in order to follow the temporal evolution of the physical, chemical and biological atmospheric-ice-ocean processes during the transition from austral spring to summer (Hellmer et al. 2008). Sampling of $1^{\text {st }}$ year sea ice was conducted on a $20 \mathrm{~m} \times 20 \mathrm{~m}$ site, located $1 \mathrm{~km}$ away from the research vessel, using precautions to avoid metal and organic matter contamination. Field operators worked upwind, wore clean 
room garments (Tyvek overall, overshoes and polyethylene gloves) and used non-contaminating equipment to collect sea ice and seawater samples (Lannuzel et al. 2006; Dumont et al. 2009). Detail on the sampling site is reported in Tison et al. (2008).

The 90-cm-long ice cores were sliced into 6-cm-thick sections, transferred into acid-washed polyethylene containers and processed onboard for the analysis of Chlorophyll $a(\mathrm{Chl} a)$ and microscopic investigations. Sea ice sections were transferred into pre-combusted $\left(450{ }^{\circ} \mathrm{C}, 4 \mathrm{~h}\right)$ glass beakers for dissolved organic carbon (DOC) and particulate organic carbon (POC) determination. Seawater (ice-water interface and $30 \mathrm{~m}$ depth) was collected using a portable peristaltic pump (Cole-Parmer, Masterflex E/P) and acid-cleaned C-flex tubing. Seawater samples were transferred into acid-washed bottles thoroughly rinsed with the collected samples. Sampling was carried out on seven occasions, between 29 November 2004 and 30 December 2004, at regular time intervals (typically every 5 days) to study the vertical and seasonal distribution of the microbial communities in the sea ice environment.

\section{Measured parameters}

\section{Temperature, salinity and brine volume fraction}

Sea ice texture, temperature and salinity of the ice cover were determined as detailed in Tison et al. (2008). Brine volume fraction was calculated from temperature and salinity data following Cox and Weeks (1998) and Eicken (2003). During the sequential melting experiment in the home laboratory, seawater temperature was monitored using a general-purpose laboratory thermometer, and the salinity was determined using a portable salinometer Global Water PC300 with an accuracy of \pm 0.003 .

\section{Iron}

Sea ice sections were melted in the dark at $4{ }^{\circ} \mathrm{C}$ and then passed through $0.2-\mu \mathrm{m}$ polycarbonate filters. Seawater samples and microcosm sub-samples were filtered the same way. Plasticware (low density polyethylene LDPE and high density polyethylene HDPE) used for trace-metal work was cleaned as follows: first soaked in a detergent bath (RBS $5 \% \mathrm{v}: \mathrm{v})$ for $24 \mathrm{~h}$, followed by three rinses with deionized water and three rinses with ultra high purity water (UHP) (18.2 M $\Omega$ Millipore milli-Q system) before being filled with $6 \mathrm{M} \mathrm{HCl}$ (Merck, reagent grade) for 1 week. In a trace-metal clean room, items were then rinsed five times with UHP water and dried inside a class-100 laminar flow hood. Twenty litre polycarbonate (PC) carboys (Nalgene) used for microcosms were treated the same way, albeit a weaker acid soak (1 M HCl, Merck, reagent grade).
Acid-cleaned bottles and containers were sealed in triple plastic bags until use. PC filters $(0.2 \mu \mathrm{m}$ porosity, $47 \mathrm{~mm}$ diameter, Nuclepore) were treated in $1 \mathrm{M} \mathrm{HCl}$ ultrapure (Ultrex, JT Baker) for 1 week before being gently rinsed five times and stored in UHP until use. Samples collected for $\mathrm{Fe}$ analysis were stored in acid-cleaned LDPE bottles and acidified to $\mathrm{pH} 1.8$ with ultrapure $\mathrm{HNO}_{3}$ (Ultrex, JT Baker). Total dissolvable $\mathrm{Fe}$ (TDFe, unfiltered) and dissolved $\mathrm{Fe}(\mathrm{DFe}$, filtered through $0.2-\mu \mathrm{m}$ Nuclepore PC filters) samples from the microcosms were measured onboard by flow injection analysis following Lannuzel et al. (2006). TDFe samples from the sequential experiment were analysed in the home laboratory 6 months after collection by isotopic dilution combined with multiple collector inductively coupled plasma mass spectrometry (IDMC-ICP-MS) using nitrilotriacetic acid chelating resin for pre-concentration and matrix separation (de Jong et al. 2008).

\section{Dissolved and particulate organic carbon}

POC was collected on pre-combusted $\left(450{ }^{\circ} \mathrm{C}, 4 \mathrm{~h}\right)$ Whatman $\mathrm{GF} / \mathrm{F}$ filters and stored in polystyrene petri dishes at $-20{ }^{\circ} \mathrm{C}$ until analysis. After drying the filters at $60{ }^{\circ} \mathrm{C}$, inorganic carbon was removed by adding $100 \mu \mathrm{L}$ of concentrated Hydrochloric acid ( $\mathrm{HCl}$, Merck Suprapure) on the filters. POC then was analysed with a Fisons NA-1500 elemental analyser. Filtered samples for DOC were stored in pre-combusted $\left(450{ }^{\circ} \mathrm{C}, 4 \mathrm{~h}\right) 20-\mathrm{ml}$ glass ampoules with $25 \mu \mathrm{H}_{3} \mathrm{PO}_{4}$ (Merck, Suprapure) and sealed to avoid contact with the atmosphere. Samples were kept in the dark at $4{ }^{\circ} \mathrm{C}$ until analysis. DOC was measured by high temperature catalytic oxidation (HTCO; procedure of Sugimura and Suzuki 1988) with a Dohrmann Apollo 9000 instrument.

\section{Chlorophyll a}

Ice core sections were melted in the dark at $4{ }^{\circ} \mathrm{C}$ in $0.2-\mu \mathrm{m}$-prefiltered seawater (1:4, v:v) and filtered onto $0.8-\mu \mathrm{m}$ GF/F filters (Whatmann) for the determination of Chl $a$. Sub-samples from the microcosm experiments were sequentially filtered onto 10 - and $0.8-\mu \mathrm{m} \mathrm{GF} / \mathrm{F}$ filters (Whatmann). Pigments deposited on the filters were then extracted in $90 \%$ (v:v) acetone in the dark at $4{ }^{\circ} \mathrm{C}$ for $24 \mathrm{~h}$ and quantified using a Kontron SFM 25 fluorometer calibrated with a Chl $a$ standard solution (Anacystis nidulans algae, Sigma) according to Yentsch and Menzel (1963).

\section{Abundance and biomass of bacteria, algae and protozoa}

Ice core sections sampled for the determination of abundance and biomass of microorganisms were melted in the dark at $4{ }^{\circ} \mathrm{C}$ in $0.2-\mu \mathrm{m}$-prefiltered seawater $(1: 4$, v:v). 
Algae and protozoa from the melted ice, seawater and microcosms were enumerated by inverted light microscopy (Utermöhl 1958) and by epifluorescence microscopy after DAPI staining (Porter and Feig 1980) as explained in details in Becquevort et al. (2009). Algae and protozoa biomasses were estimated from cell biovolumes using a set of geometric correspondences (Hillebrand et al. 1999) and specific carbon to volume relationship (Menden-Deuer and Lessard 2000). In the microcosms experiments, protozoa biomass was assessed on the $1^{\text {st }}$ and last day of the experiment. Bacteria were enumerated by epifluorescence after DAPI staining. A minimum of 100 cells were counted in at least 20 different fields at 1,000 times magnification. Bacterial biovolumes were determined by image analysis (Lucia 4.6 software) using geometric (Watson et al. 1977) and converted to carbon biomass using carbon to volume relationships (Simon and Azam 1989): $C=92 \mathrm{~V}^{0.598}$ where $\mathrm{C}$ is the carbon per cell $\left(\mathrm{fg} \mathrm{C}\right.$ cell ${ }^{-1}$ ) and $\mathrm{V}$ is the biovolume $\left(\mu \mathrm{m}^{3}\right)$.

\section{Experiments}

\section{Microcosms}

The four microcosms were set up following Mathot et al. (1991) and Giesenhagen et al. (1999) protocols. Our priority being the prevention of contamination, handling of the samples was carried out in a clean container under a Class-100 trace-metal clean laminar flow hood. The experiment was conducted on 09 December (A) and on 25 December (B) using sea ice (bottom section) and seawater (30 $\mathrm{m}$ deep). Seawater was pre-filtered using $0.2-\mu \mathrm{m}$ membrane cartridges (Sartobran 300 sterile capsule). A $10-\mathrm{cm}$ section of bottom sea ice was thawed in $3 \mathrm{~L}$ of filtered seawater $(1: 4, \mathrm{v}: \mathrm{v})$ at $4{ }^{\circ} \mathrm{C}$ in the dark (total volume sea ice + seawater $=3.7 \mathrm{~L})$. One litre of this solution was then filtered $\left(\mathrm{SI}_{\mathrm{f}}\right)$ onto $0.2-\mu \mathrm{m}$ acid-cleaned $\mathrm{PC}$ filter $(\mathrm{Nu}-$ clepore), using a PC Sartorius filtration unit and a handpump (Nalgene).

The first 20-L PC carboy contained only unfiltered seawater $\left(\mathrm{SW}_{\text {unf }}\right)$ and was used as a control to follow the growth of the planktonic community in ice-free waters. The second microcosm $\left(\mathrm{SW}_{\mathrm{unf}}+\mathrm{SI}_{\mathrm{unf}}\right)$ was a mix of $20 \mathrm{~L}$ of unfiltered seawater and $1 \mathrm{~L}$ of the sea ice solution and was meant to mimic natural conditions. The third microcosm $\left(\mathrm{SW}_{\mathrm{f}}+\mathrm{SI}_{\mathrm{unf}}\right)$ aimed at studying the fate of sea ice organisms in seawater. In this case, $1 \mathrm{~L}$ of sea ice solution was added to $20 \mathrm{~L}$ of filtered seawater. Finally, the fourth microcosm $\left(\mathrm{SW}_{\text {unf }}+\mathrm{SI}_{\mathrm{f}}\right)$ was $20 \mathrm{~L}$ of seawater spiked with $1 \mathrm{~L}$ of filtered sea ice solution. $\mathrm{SW}_{\mathrm{unf}}+\mathrm{SI}_{\mathrm{f}}$ was meant to assess the growth of planktonic organisms when sea ice melts (Table 1). The final sea ice to seawater volume ratio was $1: 80$, which represents the melting of 10-cm-thick sea ice in an $8 \mathrm{~m}$ deep mixed layer.

The $20-\mathrm{L}$ carboys were incubated at $-1{ }^{\circ} \mathrm{C}$ in the ship's culture room and exposed to a continuous light intensity of $45 \mu \mathrm{E} \mathrm{m}^{-2} \mathrm{~s}^{-1}$. The carboys were sub-sampled under trace-metal clean conditions almost daily for 10 days in order to follow the evolution of DOC, POC and microorganisms (algae, bacteria and protozoa). Protozoan biomass was assessed on the 1st and last days of the microcosm experiments. Total dissolvable Fe (TDFe, unfiltered, $\mathrm{pH}$ 1.8) was measured at the start of the two experiments. DFe represents the fraction of Fe readily available for biological uptake, while TDFe represents the fraction of Fe that can become bioavailable for microorganisms (e.g. via remineralization processes). We therefore chose to consider TDFe rather than DFe.

\section{Sequential melting}

A final experiment was performed in the home laboratory under temperature controlled and trace-metal clean conditions to study the release of sea ice components (salt, organic matter and $\mathrm{Fe}$ ). Equipment in contact with the seawater and/or sea ice was acid-cleaned before the start of the experiment. Seawater used in this experiment was collected during the CLIVAR SR3 cruise in the Antarctic Pacific sector $\left(135-150^{\circ} \mathrm{E}\right)$ in December 2001. A volume of 13.57 L was filtered through a $0.2-\mu \mathrm{m}$ Sartobran ${ }^{\circledR} 300$ cartridge and transferred in a 20-L HDPE container, at $2{ }^{\circ} \mathrm{C}$, in the dark. The melting chamber simulated the melting of sea ice as the air temperature increased, without increasing the seawater temperature. Constant mixing was applied, and a tube filled with ethanol connected to a thermostatic water bath helped maintain seawater at $-1.9^{\circ} \mathrm{C}$. A 20 -cm-thick frozen bottom ice section (diameter $=14 \mathrm{~cm}$; melted volume $=1.54 \mathrm{~L}$ ) sampled on 04 December during ISPOL was allowed to melt into this 20-L HDPE container filled with seawater (final sea ice to seawater volume ratio $\approx 1: 10$ ). Meltwater was sampled using a peristaltic pump (Masterflex) and a tube placed at the bottom of the HDPE container. Salinity, temperature, TDFe, DOC and POC concentrations were monitored until complete melting of the ice was achieved $(54 \mathrm{~h})$. For each sampling at time $(\mathrm{t})$, a second meltwater sample ( $\left.\mathrm{t}^{\prime}\right)$ was collected and left in the chamber until the time step $(\mathrm{t}+1)$. This was done to obtain the contribution of sea ice melting only $\left(C_{t+1}-C_{t}\right)$. For each parameter, fluxes from the sea ice were estimated using the equation $\mathrm{F}_{\mathrm{t}+1}=\left(\mathrm{C}_{\mathrm{t}+1}-\mathrm{C}_{\mathrm{t}}\right)^{*} \mathrm{~V} / \mathrm{t}$, with $\mathrm{C}$ the concentration of the compound, $\mathrm{V}$ the volume of solution left in the carboy and the time elapsed between $\mathrm{t}+1$ and $\mathrm{t}$. $\mathrm{V}$ takes into account the volume of melted sea ice added (averaged melting rate $=28.2 \mathrm{~mL} \mathrm{~h}^{-1}$ ) as well as the volume of solution sub-sampled at each time step. 
Table 1 Characteristics of the microcosms experiments $\mathrm{A}$ and $\mathrm{B}$

\begin{tabular}{llll}
\hline Microcosm & Seawater & Sea ice & Aim of the microcosm \\
\hline $\mathrm{SW}_{\text {unf }}$ & Unfiltered & None & $\begin{array}{c}\text { Growth of planktonic biota } \\
\text { without sea ice } \\
\text { "Natural" simulation }\end{array}$ \\
$\mathrm{SW}_{\text {unf }}+\mathrm{SI}_{\text {unf }}$ & Unfiltered & Unfiltered & $\begin{array}{c}\text { Growth of ice-derived biota in } \\
\text { seawater }\end{array}$ \\
$\mathrm{SW}_{\mathrm{f}}+\mathrm{SI}_{\mathrm{unf}}$ & Filtered & Unfiltered & $\begin{array}{c}\text { Impact of ice-derived nutrients } \\
\text { on planktonic biota }\end{array}$ \\
$\mathrm{SW}_{\text {unf }}+\mathrm{SI}_{\mathrm{f}}$ & Unfiltered & Filtered & \\
\hline
\end{tabular}

\section{Results}

Field observations

\section{Sea ice thermodynamics}

Detailed thermodynamics and chemical properties of the ISPOL drifting station are presented in Tison et al. (2008) and Lannuzel et al. (2008). To summarize, the visited ice floe was approximately $90-\mathrm{cm}$-thick $1^{\text {st }}$ year sea ice with a $10-\mathrm{cm}$ layer of granular ice (frazil) underlain with columnar ice (Tison et al. 2008). The freeboard was positive during the whole time series. Ice temperatures in the visited area were above $-5^{\circ} \mathrm{C}$ and showed clear signs of warm "springsummer" regime (Table 2). Brine volume fractions indicate that the ice cover was highly permeable upon arrival on site, with values greater than the $5 \%$ permeability threshold along the entire profile (Golden et al. 1998; Table 2). The beginning of the sampling period was characterized by intense gravitydriven brine drainage. As brine salinity became lower than seawater salinity, molecular diffusion, a much slower process, then took place as the principal pathway for the transfer of dissolved material at the ice-water interface.

\section{Iron, organic matter and Chla}

TDFe concentrations ranged from 2.3 to $97.8 \mathrm{nmol} \mathrm{L}^{-1}$ in sea ice and from 0.5 to $4.1 \mathrm{nmol} \mathrm{L}^{-1}$ in underlying seawater (Table 2). DOC and POC concentrations in sea ice ranged, respectively, from 1,273 to $8,413 \mu \mathrm{g} \mathrm{C} \mathrm{L}^{-1}$ and from 93 to $5,640 \mu \mathrm{g} \mathrm{C} \mathrm{L}^{-1}$. Maximum POC values were measured in the bottom layers, while lower values were observed in intermediate layers. In seawater, POC ranged between 12 and $130 \mu \mathrm{g} \mathrm{C} \mathrm{L}^{-1}$, while DOC was unfortunately not measured. Chla ranged from 0.08 to $28.41 \mu \mathrm{g} \mathrm{L}^{-1}$ in sea ice with the maximum values observed in basal ice. Seawater Chla increased with time ( 0.03 to $\left.0.21 \mu \mathrm{g} \mathrm{L}^{-1}\right)$ and remained always lower than in sea ice.

\section{Autotrophs}

Taxonomic similarity between the ice-derived and planktonic communities was observed during the time series
(Fig. 2). Autotrophic microorganisms represented $82 \pm$ $16 \%$ of the total biomass in sea ice, especially in the surface $(90 \pm 7 \%)$ and bottom ice layers $(96 \pm 7 \%)$. In surface sea ice $(3-9 \mathrm{~cm})$, Phaeocystis single cells dominated in terms of abundance and biomass. Some colonies were also observed, but their biomass remained low. In contrast, pennate diatoms dominated the abundance and the biomass of the autotrophic microorganisms in the bottom sea ice. Fragilariopsis sp. was the main pennate diatom present in abundance and biomass in surface sea ice. In bottom sea ice, Cylindrotheca $\mathrm{sp}$. and Nitzschia $(<10 \mu \mathrm{m})$ were the most abundant, whereas in term of biomass, Amphiprora sp. $(>10 \mu \mathrm{m})$ became predominant.

In seawater, autotrophic organisms represented $41 \pm$ $13 \%$ of the total biomass. Phaeocystis single cells were the most abundant. However, the pattern of species in seawater was patchier than in sea ice (Fig. 2), with for example autotrophic dinoflagellates contributing to $9 \pm 7 \%$ of the total biomass. A more heterogeneous distribution of pennate diatoms (Fragilariopsis sp.) and centric diatoms (Chaetoceros sp., Biddulphia sp., Corethron sp.) was also observed. At $30 \mathrm{~m}$ deep, autotrophic biomasses increased fivefold between the 29 November and the 30 December, due to an increase in pennate and centric diatoms.

\section{Heterotrophs}

Heterotrophic microorganisms (bacteria and protozoa) were present in the ice, with protozoa accounting for $48 \pm 23 \%$ of the total heterotrophic biomass. The distribution of protozoa showed maximum concentrations in the bottom ice (Fig. 2). The protozoan biomass was mainly composed of flagellates, dinoflagellates and sarcodines. The protozoan biomass showed exceptionally high value on the 30 December in bottom ice $\left(507.51 \mu \mathrm{g} \mathrm{C} \mathrm{L}^{-1}\right)$. The bacterial biomass ranged from 1.75 to $13.83 \mu \mathrm{g} \mathrm{C} \mathrm{L}^{-1}$ in sea ice, with a fairly homogeneous distribution along the ice core.

In seawater, protozoa biomass varied between 0.12 and $2.90 \mu \mathrm{g} \mathrm{C} \mathrm{L}^{-1}$ and was mainly composed of flagellates, dinoflagellates and ciliates (Fig. 2). The protozoan biomass increased over time and reached maximum concentration on 19 December in surface waters and then decreased. 
Table 2 Summary of sea ice temperature (Temp), brine volume fraction (Vb/V), Chlorophyll $a(\mathrm{Chl} a)$, particulate organic carbon (POC), dissolved organic carbon (DOC) and total dissolvable iron (TDFe) concentrations in sea ice and seawater during the ISPOL time series

\begin{tabular}{|c|c|c|c|c|c|c|c|c|}
\hline $\begin{array}{l}\text { Date } \\
\text { dd-mm-yyyy }\end{array}$ & Type of sample & Depth & $\begin{array}{l}\text { Temp } \\
{ }^{\circ} \mathrm{C}\end{array}$ & $\begin{array}{l}\mathrm{Vb} / \mathrm{V} \\
\%\end{array}$ & $\begin{array}{l}\text { Chla } \\
\mu \mathrm{g} \mathrm{L}^{-1}\end{array}$ & $\begin{array}{l}\text { TDFe } \\
\text { nmol L }\end{array}$ & $\begin{array}{l}\text { POC } \\
\mu \mathrm{g} \mathrm{L}^{-1}\end{array}$ & $\begin{array}{l}\text { DOC } \\
\mu \mathrm{g} \mathrm{L}^{-1}\end{array}$ \\
\hline \multirow[t]{9}{*}{ 29-Nov-2004 } & Sea ice & $3-9 \mathrm{~cm}$ & -3.1 & 15 & 0.36 & 57 & 684 & $n a$ \\
\hline & Sea ice & $9-15 \mathrm{~cm}$ & -2.4 & 16 & 0.41 & 57 & 541 & $n a$ \\
\hline & Sea ice & $40-46 \mathrm{~cm}$ & -2.3 & 13 & 0.18 & 21.7 & 172 & $n a$ \\
\hline & Sea ice & $60-66 \mathrm{~cm}$ & -2.1 & 11 & 0.08 & 42.6 & 112 & $n a$ \\
\hline & Sea ice & $78-84 \mathrm{~cm}$ & -2 & 14 & 3.98 & $n a$ & 621 & $n a$ \\
\hline & Sea ice & $84-90 \mathrm{~cm}$ & -1.9 & 26 & 23.57 & 97.8 & 3,766 & $n a$ \\
\hline & Seawater & $0 \mathrm{~m}$ & & & 0.030 & 1.4 & 33 & $n a$ \\
\hline & Seawater & $1 \mathrm{~m}$ & & & 0.038 & 1.5 & $<d l$ & na \\
\hline & Seawater & $30 \mathrm{~m}$ & & & 0.033 & 1.6 & 1 & $n a$ \\
\hline \multirow[t]{9}{*}{ 4-Dec-2004 } & Sea ice & $3-9 \mathrm{~cm}$ & -1.7 & 16 & 0.44 & 55.1 & 565 & na \\
\hline & Sea ice & $9-15 \mathrm{~cm}$ & -2.1 & 13 & 0.44 & na & 428 & na \\
\hline & Sea ice & $40-46 \mathrm{~cm}$ & -1.9 & 13 & 0.45 & 10.1 & 167 & 8,004 \\
\hline & Sea ice & $60-66 \mathrm{~cm}$ & -1.6 & 8 & 0.16 & 8.2 & 232 & 4,662 \\
\hline & Sea ice & $78-84 \mathrm{~cm}$ & -1.8 & 14 & 3.44 & na & 741 & 4,109 \\
\hline & Sea ice & $84-90 \mathrm{~cm}$ & -1.8 & 25 & 26.47 & 21.2 & 3,175 & 8,413 \\
\hline & Seawater & $0 \mathrm{~m}$ & & & 0.05 & 1.6 & $<d l$ & $n a$ \\
\hline & Seawater & $1 \mathrm{~m}$ & & & 0.05 & 1.7 & 3 & $n a$ \\
\hline & Seawater & $30 \mathrm{~m}$ & & & 0.05 & $n a$ & $n a$ & $n a$ \\
\hline \multirow[t]{9}{*}{ 9-Dec-2004 } & Sea ice & $3-9 \mathrm{~cm}$ & -1.2 & 15 & 0.97 & 22.7 & 595 & 2,452 \\
\hline & Sea ice & $9-15 \mathrm{~cm}$ & -1.4 & 16 & 2.22 & $n a$ & 903 & 5,669 \\
\hline & Sea ice & $40-46 \mathrm{~cm}$ & -1.9 & 14 & 0.4 & 2.7 & 279 & 3,104 \\
\hline & Sea ice & $60-66 \mathrm{~cm}$ & -1.8 & 14 & 0.25 & 5.1 & 191 & 5,212 \\
\hline & Sea ice & $78-84 \mathrm{~cm}$ & -1.8 & 17 & 2.56 & $n a$ & 1,138 & 1,656 \\
\hline & Sea ice & $84-90 \mathrm{~cm}$ & -1.8 & 14 & 21.48 & 12.5 & 4,754 & 5,649 \\
\hline & Seawater & $0 \mathrm{~m}$ & & & 0.06 & 2.6 & 24 & $n a$ \\
\hline & Seawater & $1 \mathrm{~m}$ & & & 0.06 & 1.6 & $<d l$ & $n a$ \\
\hline & Seawater & $30 \mathrm{~m}$ & & & 0.06 & $n a$ & 13 & na \\
\hline \multirow[t]{9}{*}{ 14-Dec-2004 } & Sea ice & $0-9 \mathrm{~cm}$ & -1.5 & 25 & 0.69 & 19.3 & 725 & 6,845 \\
\hline & Sea ice & $9-15 \mathrm{~cm}$ & -1.4 & 17 & 1.23 & 7.1 & 766 & 4,152 \\
\hline & Sea ice & $40-46 \mathrm{~cm}$ & -1.7 & 11 & 0.27 & 5.3 & 327 & 4,483 \\
\hline & Sea ice & $60-66 \mathrm{~cm}$ & -1.7 & 10 & 0.3 & 3.5 & 451 & 3,856 \\
\hline & Sea ice & $74-80 \mathrm{~cm}$ & -1.8 & 12 & 2.19 & $n a$ & 773 & 5,305 \\
\hline & Sea ice & $80-86 \mathrm{~cm}$ & -1.9 & 21 & 24.23 & 22 & 5,640 & 5,717 \\
\hline & Seawater & $0 \mathrm{~m}$ & & & 0.06 & 1.8 & 56 & $n a$ \\
\hline & Seawater & $1 \mathrm{~m}$ & & & 0.1 & 0.5 & 58 & $n a$ \\
\hline & Seawater & $30 \mathrm{~m}$ & & & 0.09 & 1.8 & 36 & $n a$ \\
\hline \multirow[t]{9}{*}{ 19-Dec-2004 } & Sea ice & $4-10 \mathrm{~cm}$ & -0.4 & 33 & 0.78 & 24.7 & 282 & 3,629 \\
\hline & Sea ice & $10-16 \mathrm{~cm}$ & -1.3 & 30 & 1.06 & $n a$ & 306 & 3,561 \\
\hline & Sea ice & $40-46 \mathrm{~cm}$ & -1.4 & 17 & 0.2 & 5.1 & 181 & 3,615 \\
\hline & Sea ice & $60-66 \mathrm{~cm}$ & -1.5 & 11 & 0.65 & 3 & 223 & 2,408 \\
\hline & Sea ice & $77-83 \mathrm{~cm}$ & -1.6 & 10 & 4.21 & na & 618 & 3,179 \\
\hline & Sea ice & $83-89 \mathrm{~m}$ & -1.6 & 16 & 28.41 & 14.7 & 2,061 & 4,242 \\
\hline & Seawater & $0 \mathrm{~m}$ & & & 0.11 & 3.2 & 69 & $n a$ \\
\hline & Seawater & $1 \mathrm{~m}$ & & & 0.09 & 2.2 & 162 & $n a$ \\
\hline & Seawater & $30 \mathrm{~m}$ & & & 0.13 & $n a$ & 46 & $n a$ \\
\hline
\end{tabular}


Table 2 continued

\begin{tabular}{|c|c|c|c|c|c|c|c|c|}
\hline $\begin{array}{l}\text { Date } \\
\text { dd-mm-yyyy }\end{array}$ & Type of sample & Depth & $\begin{array}{l}\text { Temp } \\
{ }^{\circ} \mathrm{C}\end{array}$ & $\begin{array}{l}\mathrm{Vb} / \mathrm{V} \\
\%\end{array}$ & $\begin{array}{l}\text { Chla } \\
\mu \mathrm{g} \mathrm{L}^{-1}\end{array}$ & $\begin{array}{l}\text { TDFe } \\
\mathrm{nmol} \mathrm{L}^{-1}\end{array}$ & $\begin{array}{l}\text { POC } \\
\mu \mathrm{g} \mathrm{L}^{-1}\end{array}$ & $\begin{array}{l}\text { DOC } \\
\mu \mathrm{g} \mathrm{L}^{-1}\end{array}$ \\
\hline \multirow[t]{9}{*}{ 25-Dec-2004 } & Sea ice & $3-9 \mathrm{~cm}$ & -0.2 & 11 & 0.7 & 10.7 & 93 & $n a$ \\
\hline & Sea ice & $9-15 \mathrm{~cm}$ & -0.7 & 14 & 0.66 & $n a$ & 242 & na \\
\hline & Sea ice & $40-46 \mathrm{~cm}$ & -1.2 & 21 & 0.69 & 4 & 146 & $n a$ \\
\hline & Sea ice & $60-66 \mathrm{~cm}$ & -1.2 & 16 & 0.29 & 2.3 & 148 & $n a$ \\
\hline & Sea ice & $74-84 \mathrm{~cm}$ & -1.2 & 15 & 3.3 & $n a$ & 496 & $n a$ \\
\hline & Sea ice & $84-90 \mathrm{~cm}$ & -1.4 & 17 & 16.33 & 8.4 & 2,515 & $n a$ \\
\hline & Seawater & $0 \mathrm{~m}$ & & & 0.21 & 2.4 & 38 & $n a$ \\
\hline & Seawater & $1 \mathrm{~m}$ & & & 0.16 & 1.6 & $<d l$ & $n a$ \\
\hline & Seawater & $30 \mathrm{~m}$ & & & 0.12 & 2.3 & 94 & $n a$ \\
\hline \multirow[t]{9}{*}{ 30-Dec-2004 } & Sea ice & $3-9 \mathrm{~cm}$ & -1.1 & 20 & 1.69 & 14.1 & 357 & 5,255 \\
\hline & Sea ice & $9-16 \mathrm{~cm}$ & -1.2 & 16 & 0.97 & $n a$ & 342 & 5,488 \\
\hline & Sea ice & $40-46 \mathrm{~cm}$ & -1.4 & 13 & 0.59 & 4.8 & 364 & 2,762 \\
\hline & Sea ice & $59-65 \mathrm{~cm}$ & -1.4 & 9 & 0.95 & 2.7 & $n a$ & 1,273 \\
\hline & Sea ice & $74-80 \mathrm{~cm}$ & -1.6 & 11 & 3.62 & $n a$ & 534 & 1,273 \\
\hline & Sea ice & $80-86 \mathrm{~cm}$ & -1.8 & 17 & 24.77 & 15.8 & 2,008 & 2,494 \\
\hline & Seawater & $0 \mathrm{~m}$ & & & 0.14 & 2.3 & 64 & $n a$ \\
\hline & Seawater & $1 \mathrm{~m}$ & & & 0.14 & 1.5 & 124 & $n a$ \\
\hline & Seawater & $30 \mathrm{~m}$ & & & 0.15 & 4.1 & 41 & $n a$ \\
\hline
\end{tabular}

DOC and POC are reported in Dumont et al. (2009). Iron data are presented in Lannuzel et al. (2008)

na not assessed, $<d l$ below detection limit

The bacterial biomass in seawater ranged from 0.37 to $1.71 \mu \mathrm{g} \mathrm{C} \mathrm{L}^{-1}$. Like protozoa, values were maximal on 19 December, but no clear seasonal trend was observed over the sampling period.

\section{Microcosms}

\section{Supply of microorganisms, organic carbon and iron into the water column}

When comparing $\mathrm{SW}_{\text {unf }}{ }^{-} \mathrm{A}$ and $\mathrm{SW}_{\text {unf }}-\mathrm{B}$ with $\mathrm{SW}_{\mathrm{unf}}+$ $\mathrm{SI}_{\text {unf }}-\mathrm{A}$ and $\mathrm{SW}_{\text {unf }}+\mathrm{SI}_{\mathrm{unf}}-\mathrm{B}$, we can estimate the supply of autotrophs, heterotrophs, Fe, DOC and POC from melting sea ice into seawater (Table 3). Total biomasses (algae, bacteria and protozoa) were lower at the start of $\mathrm{SW}_{\mathrm{unf}}$-A than $\mathrm{SW}_{\mathrm{unf}}-\mathrm{B}$, suggesting a growth of microorganisms between the two sampling dates. This result is in agreement with our field observations in deep seawater between 9 December and 25 December (Fig. 2). However, we note that the microcosm $\mathrm{SW}_{\text {unf }}$ exhibits lower initial biomasses of phytoplankton and bacteria than the in situ sample in both experiments. The discrepancies between laboratory and field samples may be due to the grazing by protozoa during the 2 days (= melting time) elapsed between the sampling and the start of the microcosm experiments.
At the start of experiments $\mathrm{SW}_{\mathrm{unf}}{ }^{-\mathrm{A}}$ and $\mathrm{SW}_{\mathrm{unf}}-\mathrm{B}$ (9-Dec and 25-Dec), the autotrophic abundance was dominated by nanoflagellates, followed by dinoflagellates and ciliates. The autotrophic biomass was equally distributed between diatoms, nano- and dinoflagellates. The diatom biomass was mainly composed of pennates (Fragilariopsis sp.), even though some centrics were present in $\mathrm{SW}_{\text {unf }}{ }^{-} \mathrm{A}$ and even more centric was observed in $\mathrm{SW}_{\text {unf }} \mathrm{B}$ (Chaetoceros sp.). Diatoms then became the dominant group both in terms of abundance and biomass when sea ice was added $\left(\mathrm{SW}_{\mathrm{unf}}+\mathrm{SI}_{\mathrm{unf}}\right)$ in A (dominated by Amphiprora sp.) and B (dominated by Cylindrotheca sp.). The dino- and nanoflagellates biomass remained constant. The $1 \%$ of sea ice added to seawater was therefore a major supply of algal biomass, especially pennate diatoms, in both experiments (9- to 27-fold increase; Table 3). Table 3 also indicates that sea ice supplied less heterotrophs (2- to 6-fold increase in the biomass of bacteria and protozoa) than autotrophs. The protozoan abundances were actually similar in $\mathrm{SW}_{\text {unf }}-\mathrm{A}$ and $\mathrm{SW}_{\mathrm{unf}}+\mathrm{SI}_{\mathrm{unf}} \mathrm{A}$, while the protozoan biomass only slightly increased in $\mathrm{SW}_{\text {unf }}+\mathrm{SI}_{\mathrm{unf}}-\mathrm{A}$ compared to $\mathrm{SW}_{\mathrm{unf}}-\mathrm{A}$ (Table 3). In experiment $B$, we observed a slight increase in $\mathrm{SW}_{\text {unf }}+\mathrm{SI}_{\mathrm{unf}}$ compared to $\mathrm{SW}_{\text {unf }}$ both in terms of protozoan abundance (5\% increase) and biomass (20\% increase, Table 3). If bacterial abundance were similar in $\mathrm{SW}_{\text {unf }}{ }^{-} \mathrm{B}$ and $\mathrm{SW}_{\mathrm{unf}}+\mathrm{SI}_{\mathrm{unf}}-\mathrm{B}$ at the start of the experiment, bacterial biomass was slightly higher in $\mathrm{SW}_{\mathrm{unf}}+\mathrm{SI}_{\mathrm{unf}}-\mathrm{B}$ than 
autotrophs

protozoa

bacteria
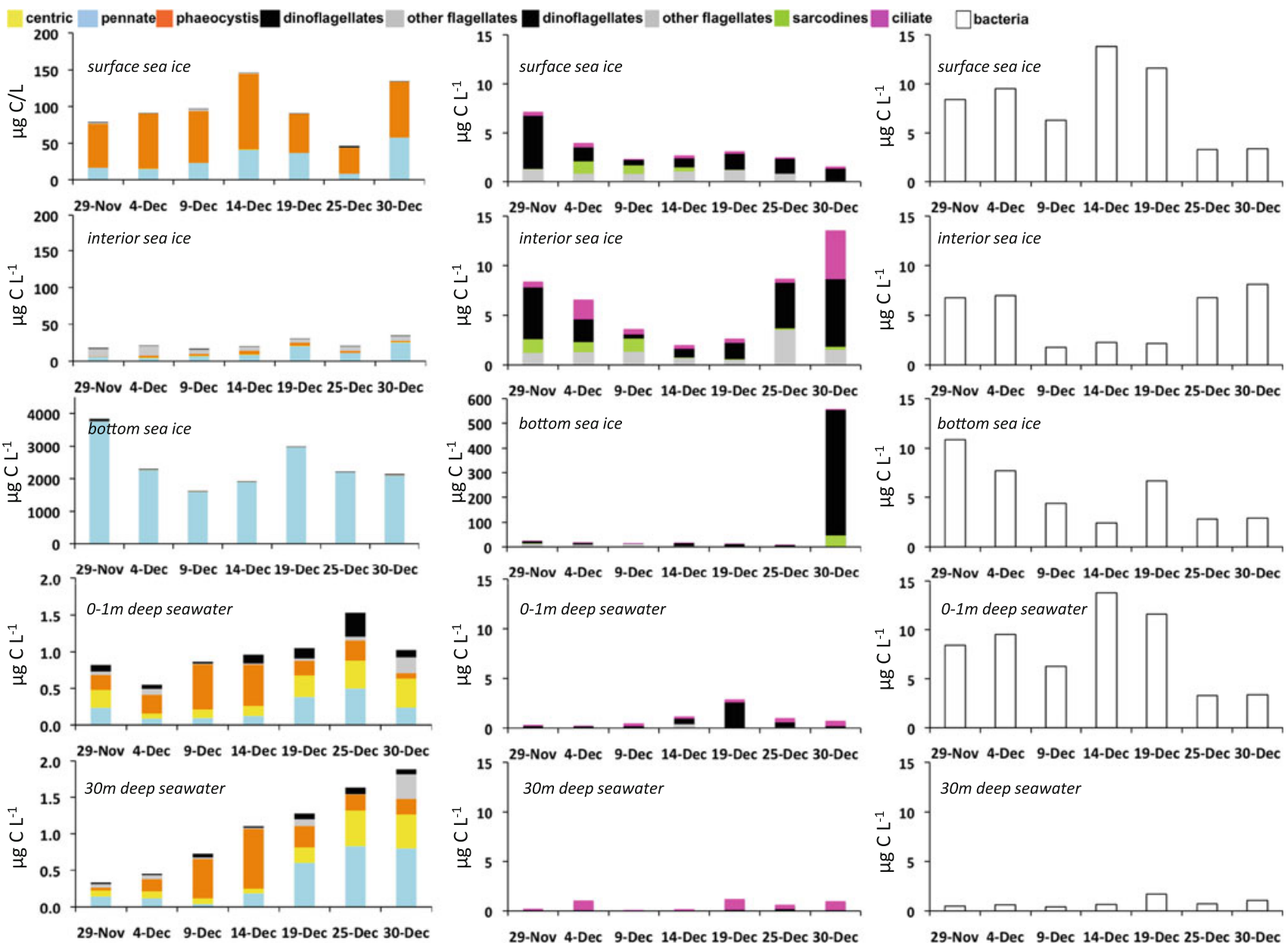

Fig. 2 Biomass distribution of autotrophs, protozoa and bacteria (in $\mu \mathrm{g} \mathrm{C} \mathrm{L}^{-1}$ ) in sea ice and seawater during the ISPOL time series. Partial taxonomic similarity is observed between the ice-derived and planktonic communities during the time series

in $\mathrm{SW}_{\mathrm{unf}}$-B. In experiment $\mathrm{A}$, bacterial abundance and biomass were surprisingly even lower in $\mathrm{SW}_{\mathrm{unf}}+\mathrm{SI}_{\mathrm{unf}}-\mathrm{A}$ than in $\mathrm{SW}_{\text {unf- }} \mathrm{A}$. Consequently, the sea ice addition decreased the initial heterotroph to autotroph ratios from 2 for $\mathrm{SW}_{\mathrm{unf}}$ to 0.05 for $\mathrm{SW}_{\mathrm{unf}}+\mathrm{SI}_{\mathrm{unf}}-\mathrm{A}$ and 0.28 for $\mathrm{SW}_{\mathrm{unf}}+\mathrm{SI}_{\mathrm{unf}}-\mathrm{B}$.

An important supply of DOC and POC was observed when sea ice was added to seawater (Table 3, DOC not measured for A). Natural seawater samples also demonstrated an increase in organic matter concentration during sea ice melting (Table 2). This increase may be due to phytoplankton growth and not solely to the seeding of POC from sea ice. On the other hand, and based on the observed concentration in the field in $30 \mathrm{~m}$ deep seawater $\left(2.3 \mathrm{nmol} \mathrm{L}^{-1}\right)$ and in bottom sea ice (8.4-12.5 $\left.\mathrm{nmol} \mathrm{L}^{-1}\right)$, the addition of sea ice to seawater would have only
Table 3 Initial concentrations of microorganisms (algae, bacteria and protozoa), dissolved and particulate organic carbon (DOC and POC), and total dissolvable iron (TDFe) in microcosms $\mathrm{SW}_{\text {unf }}$ and $\mathrm{SW}_{\text {unf }}+\mathrm{SI}_{\text {unf }}$ for experiments $\mathrm{A}$ and $\mathrm{B}$

na not assessed

\begin{tabular}{|c|c|c|c|c|c|}
\hline & & \multicolumn{2}{|l|}{ A } & \multicolumn{2}{|l|}{ B } \\
\hline & & $\mathrm{SW}_{\text {unf }}$ & $\mathrm{SW}_{\mathrm{unf}}+\mathrm{SI}_{\mathrm{unf}}$ & $\mathrm{SW}_{\mathrm{unf}}$ & $\mathrm{SW}_{\mathrm{unf}}+\mathrm{SI}_{\mathrm{unf}}$ \\
\hline Algae & $\mu \mathrm{gC} \mathrm{L}^{-1}$ & 0.16 & 4.45 & 0.64 & 6.28 \\
\hline Bacteria & $\mu \mathrm{g} \mathrm{C} \mathrm{L}^{-1}$ & 0.26 & 0.14 & 0.51 & 0.68 \\
\hline Protozoa & $\mu \mathrm{gC} \mathrm{L}^{-1}$ & 0.05 & 0.08 & 0.82 & 1.01 \\
\hline DOC & $\mu \mathrm{gC} \mathrm{L}^{-1}$ & $n a$ & $n a$ & 2,000 & 13,000 \\
\hline POC & $\mu \mathrm{gC} \mathrm{L}^{-1}$ & 167 & 318 & 95 & 127 \\
\hline $\mathrm{TDFe}$ & $\mathrm{nmol} \mathrm{L}^{-1}$ & 1.6 & 1.7 & 2.3 & 2.4 \\
\hline
\end{tabular}


Fig. 3 a Chlorophyll $a$ in the microcosms $\mathrm{SW}_{\text {unf }}$ and $\mathrm{SW}_{\mathrm{unf}}+\mathrm{SI}_{\mathrm{f}}$ for experiments $\mathrm{A}$ b Chlorophyll $a$ in the microcosms $\mathrm{SW}_{\text {unf }}$ and $\mathrm{SW}_{\mathrm{unf}}+\mathrm{SI}_{\mathrm{f}}$ for experiments B c total bacterial biomass in the microcosms $\mathrm{SW}_{\text {unf }}$ and

$\mathrm{SW}_{\mathrm{unf}}+\mathrm{SI}_{\mathrm{f}}$ for experiments A and $\mathbf{d}$ total bacterial biomass in the microcosms $\mathrm{SW}_{\text {unf }}$ and

$\mathrm{SW}_{\mathrm{unf}}+\mathrm{SI}_{\mathrm{f}}$ for experiments B. Chl $a$ associated with planktonic algae reached higher concentrations after 9 days in $\mathrm{SW}_{\mathrm{unf}}+\mathrm{SI}_{\mathrm{f}}$ than $\mathrm{SW}_{\text {unf }}$. Planktonic bacterial growth was similarly stimulated by the sea ice addition
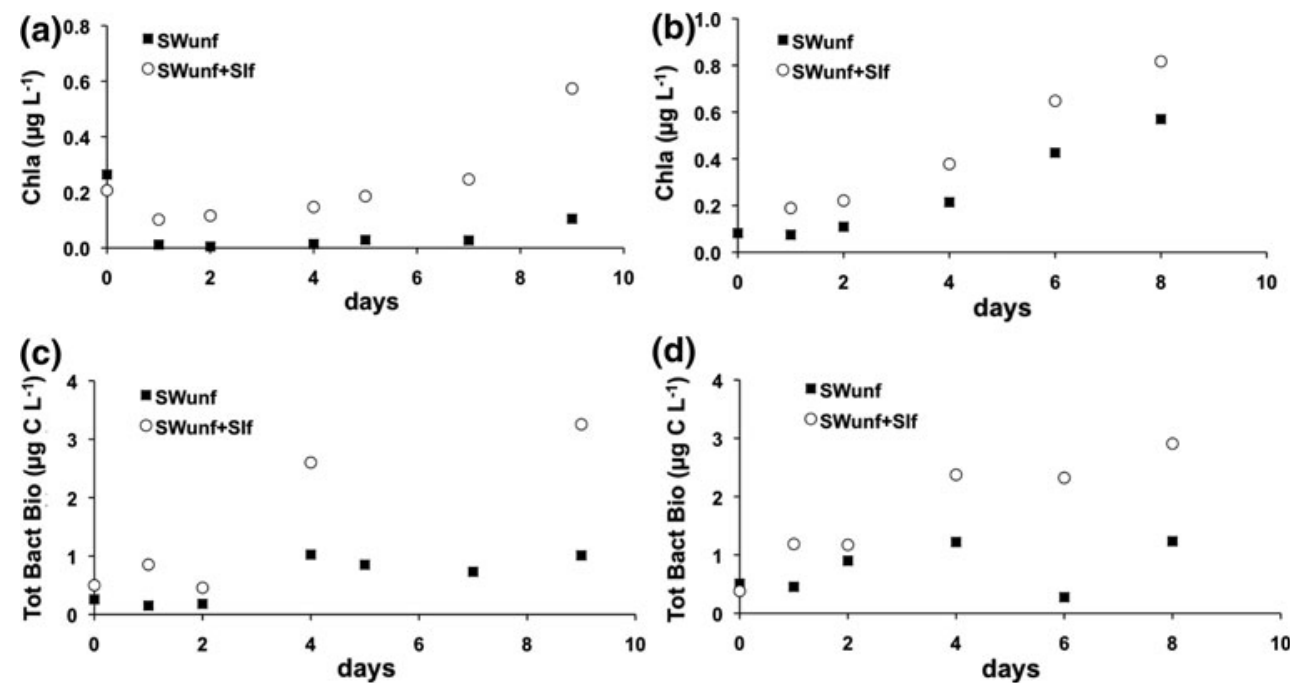

contributed to an increase of 4-5\% of the initial seawater concentration of $\mathrm{Fe}$ in the microcosms. This estimate is confirmed by the slightly higher TDFe concentrations measured at the start in $\mathrm{SW}_{\text {unf }}+\mathrm{SI}_{\text {unf }}$ compared to $\mathrm{SW}_{\text {unf }}$ (Table 3).

Supply of dissolved elements to the planktonic community

We showed here above that sea ice supplies microorganisms, organic carbon (dissolved and particulate) and Fe to a lesser extent in this study to seawater. The impact of sea ice in supplying key ingredients to seawater was further evaluated by comparing the growth of planktonic microorganisms in $\mathrm{SW}_{\text {unf }}$ and $\mathrm{SW}_{\text {unf }}+\mathrm{SI}_{\mathrm{f}}$. For both assays, Chl $a$ associated with planktonic algae reached higher concentrations after 9 days in $\mathrm{SW}_{\text {unf }}+\mathrm{SI}_{\mathrm{f}}$ than in $\mathrm{SW}_{\text {unf }}$ (Fig. 3). Chl $a$ increased from 0.20 to $0.57 \mu \mathrm{g} \mathrm{L}^{-1}$ in $\mathrm{SW}_{\text {unf }}+\mathrm{SI}_{\mathrm{f}}-\mathrm{A}$ and from 0.08 to $0.82 \mu \mathrm{g} \mathrm{L}^{-1}$ in $\mathrm{SW}_{\text {unf }}+\mathrm{SI}_{\mathrm{f}}-\mathrm{B}$ (Fig. 3). This indicates a stimulation of planktonic algal growth in response to the addition of dissolved nutrients supplied from sea ice. Note that Chl $a$ increased in $\mathrm{SW}_{\text {unf- }}{ }^{-\mathrm{B}}$ (seawater only). This could result from the relatively high initial $\mathrm{Fe}$ concentration in seawater on 25 December (i.e. TDFe $=2.3 \mathrm{nmol} \mathrm{L}^{-1}$ ) as well as favourable conditions inherent to bottle experiments (such as light and exclusion of mesozooplankton grazing).

Planktonic bacterial growth was similarly stimulated by the addition of filtered sea ice (Fig. 3). After respectively 9 and 8 days, total bacterial biomass increased sevenfold to eightfold in $\mathrm{SW}_{\text {unf }}+\mathrm{SI}_{\mathrm{f}}-\mathrm{A}$ and $\mathrm{SW}_{\text {unf }}+\mathrm{SI}_{\mathrm{f}}-\mathrm{B}$, whereas it

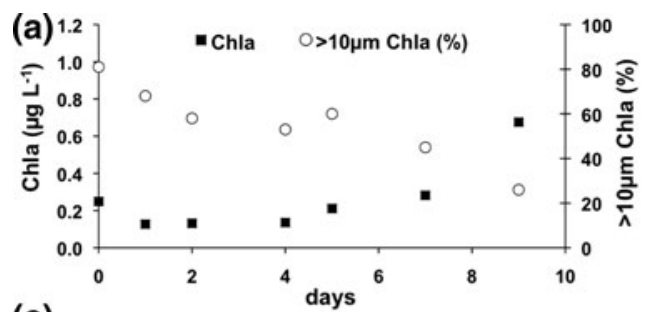

(c)

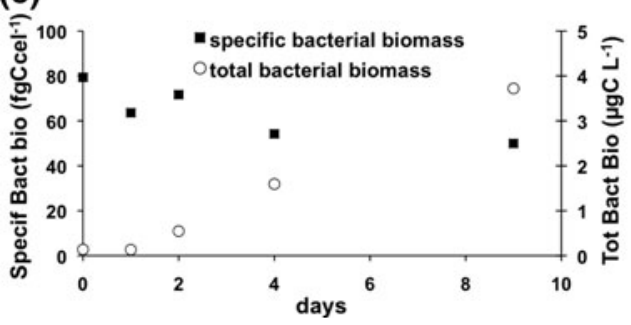

Fig. 4 a Chlorophyll $a$ and percentage of Chlorophyll $a>10 \mu \mathrm{m}$ in the microcosm $\mathrm{SW}_{\mathrm{f}}+\mathrm{SI}_{\mathrm{unf}}$ for experiment $\mathrm{A}$, b Chlorophyll $a$ and percentage of Chlorophyll $a>10 \mu \mathrm{m}$ in the microcosm $\mathrm{SW}_{\mathrm{f}}+\mathrm{SI}_{\mathrm{unf}}$ for experiment $\mathrm{B}, \mathbf{c}$ specific bacterial biomass $\left(\mathrm{fg} \mathrm{C} \mathrm{cel}^{-1}\right.$ ) and total bacterial biomass $\left(\mu \mathrm{g} \mathrm{C} \mathrm{L}^{-1}\right)$ in the microcosm $\mathrm{SW}_{\mathrm{f}}+\mathrm{SI}_{\mathrm{unf}}$ for

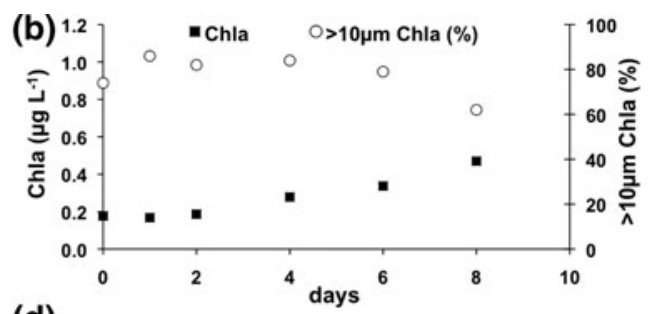

(d)

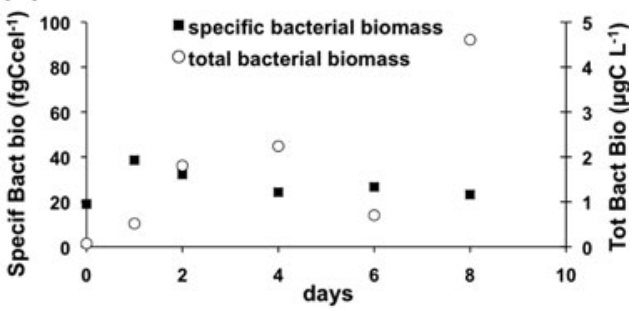

experiment $\mathrm{A}$ and $\mathbf{d}$ specific bacterial biomass (fg $\mathrm{C} \mathrm{cel}^{-1}$ ) and total bacterial biomass $\left(\mu \mathrm{g} \mathrm{C} \mathrm{L}^{-1}\right)$ in the microcosm $\mathrm{SW}_{\mathrm{f}}+\mathrm{SI}_{\mathrm{unf}}$ for experiment $\mathrm{B}$. We observed the growth of the ice-derived algae and bacteria in filtered seawater 
only increased two to fourfold in $\mathrm{SW}_{\mathrm{unf}}-\mathrm{A}$ and $\mathrm{SW}_{\mathrm{unf}}-\mathrm{B}$. Like Chla and bacteria, the protozoan biomass, particularly heterotrophic dinoflagellates, increased from 0.06 to $1.21 \mu \mathrm{g} \mathrm{C} \mathrm{L}^{-1}$ in $\mathrm{SW}_{\text {unf }}+\mathrm{SI}_{\mathrm{f}}-\mathrm{A}$ and from 0.79 to $3.62 \mu \mathrm{g} \mathrm{C} \mathrm{L}^{-1}$ in $\mathrm{SW}_{\text {unf }}+\mathrm{SI}_{\mathrm{f}}-\mathrm{B}$ (protozoa were only enumerated at the start and the end of the microcosms).

\section{Evolution of ice-derived microorganisms in seawater}

The microcosm $\mathrm{SW}_{\mathrm{f}}+\mathrm{SI}_{\mathrm{unf}}$ was designed to study the fate of sea ice microorganisms in seawater. After a latent period of 2 days, Chla increased from 0.25 to $0.68 \mu \mathrm{g} \mathrm{L}^{-1}$ after 9 days in A (Fig. 4) and from 0.18 to $0.47 \mu \mathrm{g} \mathrm{L}^{-1}$ after 8 days in B (Fig. 4). This shows that at least some of the icederived autotrophic organisms were able to grow in filtered seawater. Nevertheless, Chl $a$ associated with algae $>10 \mu \mathrm{m}$ decreased with time, particularly in A (Fig. 4), indicating that algae $<10 \mu \mathrm{m}$ were the ones growing. This result is in accordance with the shift in taxonomic composition of the algal assemblages from a dominance of Amphiprora sp. $(>10 \mu \mathrm{m})$ at time zero to Fragilariopsis sp. $(<10 \mu \mathrm{m})$ after 9 days. Similarly, sea ice bacteria seemed able to grow in seawater as shown by the increase in total biomass from 0.14 to $3.72 \mu \mathrm{g} \mathrm{C} \mathrm{L}^{-1}$ after 9 days in $\mathrm{A}$ and from 0.07 to $4.71 \mu \mathrm{g} \mathrm{C} \mathrm{L}^{-1}$ after 8 days in experiment B (Fig. 4). Like algae, a decrease in the size of bacteria was observed and specific carbon content decreased from 79 to $50 \mathrm{fg} \mathrm{Cel}^{-1}$ in A and from 53 to $24 \mathrm{fg} \mathrm{C}^{-1}$ in B (Fig. 4). While the protozoa biomass decreased from 2.92 to $0.82 \mu \mathrm{g} \mathrm{C} \mathrm{L}^{-1}$ in $\mathrm{A}$, it did increase from 1.27 to $3.83 \mu \mathrm{g} \mathrm{C} \mathrm{L}^{-1}$ in $\mathrm{B}$ when the highest bacterial size attenuation was observed (protozoa were only enumerated at the start and the end of the microcosms).
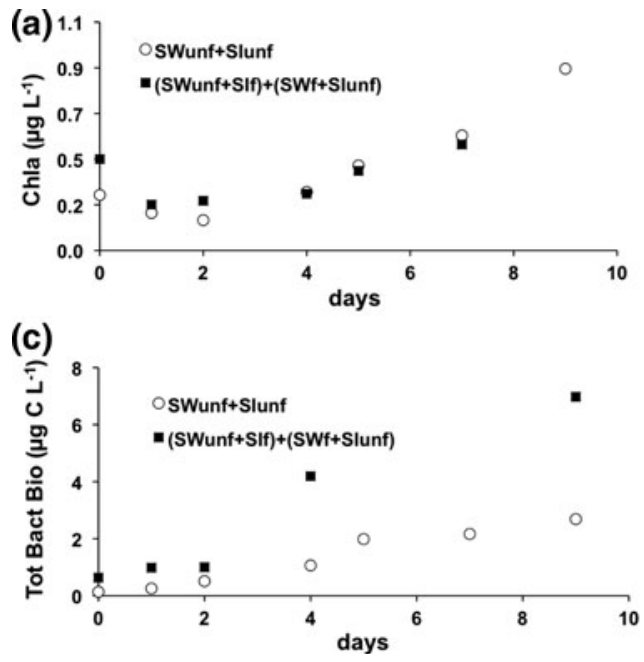

Fig. 5 a Chlorophyll $a$ in the microcosms $\mathrm{SW}_{\mathrm{unf}}+\mathrm{SI}_{\mathrm{unf}}$ and $\left(\mathrm{SW}_{\mathrm{f}}+\mathrm{SI}_{\mathrm{unf}}\right)+\left(\mathrm{SW}_{\mathrm{unf}}+\mathrm{SI}_{\mathrm{f}}\right)$ in experiment $\mathrm{A}$, b Chlorophyll $a$ in the microcosms $\mathrm{SW}_{\mathrm{unf}}+\mathrm{SI}_{\mathrm{unf}}$ and $\left(\mathrm{SW}_{\mathrm{f}}+\mathrm{SI}_{\mathrm{unf}}\right)+\left(\mathrm{SW}_{\mathrm{unf}}+\right.$ $\mathrm{SI}_{\mathrm{f}}$ ) for experiment $\mathrm{B}, \mathbf{c}$ total bacterial biomass in the microcosms $\mathrm{SW}_{\mathrm{unf}}+\mathrm{SI}_{\mathrm{unf}}$ and $\left(\mathrm{SW}_{\mathrm{f}}+\mathrm{SI}_{\mathrm{unf}}\right)+\left(\mathrm{SW}_{\mathrm{unf}}+\mathrm{SI}_{\mathrm{f}}\right)$ for experiment $\mathrm{A}$
Competition between ice-derived and planktonic microorganisms

The fore-mentioned microcosms $\left(\mathrm{SW}_{\mathrm{unf}}, \mathrm{SW}_{\mathrm{f}}+\mathrm{SI}_{\mathrm{unf}}\right.$ and $\mathrm{SW}_{\text {unf }}+\mathrm{SI}_{\mathrm{f}}$ ) intentionally exclude the direct interactions between ice-derived and planktonic microorganisms to study their effects independently. Nevertheless, competition between microorganisms, e.g. inorganic and organic nutrients, can occur in situ and result in a decrease of biomass. To study these natural interactions during sea ice melting (although grazing processes may be restricted in bottle studies), the distribution of the ice-derived and planktonic biomasses was studied together in $\mathrm{SW}_{\mathrm{unf}}+\mathrm{SI}_{\mathrm{unf}}$. By comparing the values obtained in $\mathrm{SW}_{\text {unf }}+\mathrm{SI}_{\mathrm{unf}}$ to the sum of the values obtained in $\mathrm{SW}_{\mathrm{f}}+\mathrm{SI}_{\mathrm{unf}}$ and $\mathrm{SW}_{\text {unf }}+\mathrm{SI}_{\mathrm{f}}$, we can estimate the magnitude of the interaction between ice-derived and planktonic microorganisms. Chla concentrations in $\mathrm{SW}_{\mathrm{unf}}+\mathrm{SI}_{\mathrm{unf}}$ were the same as that estimated from $\left(\mathrm{SW}_{\mathrm{f}}+\mathrm{SI}_{\mathrm{unf}}\right)+\left(\mathrm{SW}_{\mathrm{unf}}+\mathrm{SI}_{\mathrm{f}}\right)$ for A (Fig. 5), suggesting no competition between the icederived and planktonic algal communities in A. However, Chla concentrations measured in $\mathrm{SW}_{\text {unf }}+\mathrm{SI}_{\text {unf }}$ were lower than that estimated from $\left(\mathrm{SW}_{\mathrm{f}}+\mathrm{SI}_{\mathrm{unf}}\right)+\left(\mathrm{SW}_{\mathrm{unf}}+\mathrm{SI}_{\mathrm{f}}\right)$ for B (Fig. 5), indicating some competition between the icederived and planktonic algal communities in $\mathrm{B}$. Total bacterial biomasses measured in $\mathrm{SW}_{\text {unf }}+\mathrm{SI}_{\text {unf }}$ were lower than that estimated from $\left(\mathrm{SW}_{\mathrm{f}}+\mathrm{SI}_{\mathrm{unf}}\right)+\left(\mathrm{SW}_{\mathrm{unf}}+\mathrm{SI}_{\mathrm{f}}\right)$ (Fig. 5), especially for $\mathrm{A}$, indicating a competition between the icederived and planktonic bacterial communities occurred, or that the grazing pressure was higher in $\mathrm{SW}_{\mathrm{unf}}+\mathrm{SI}_{\mathrm{unf}}$. The biomass of heterotrophic nanoflagellates, grazers of bacteria, actually increased 11-fold in $\mathrm{SW}_{\mathrm{unf}}+\mathrm{SI}_{\mathrm{unf}}-\mathrm{A}$ after 9 days, therefore supporting the latter hypothesis.

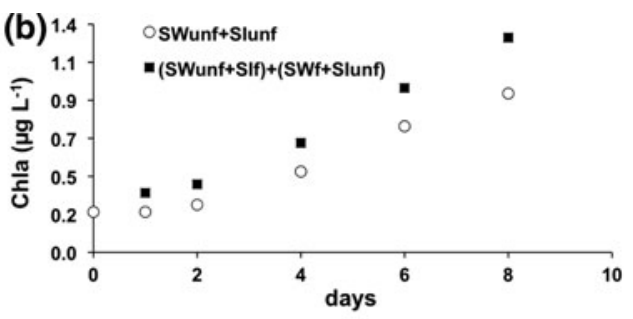

(d)

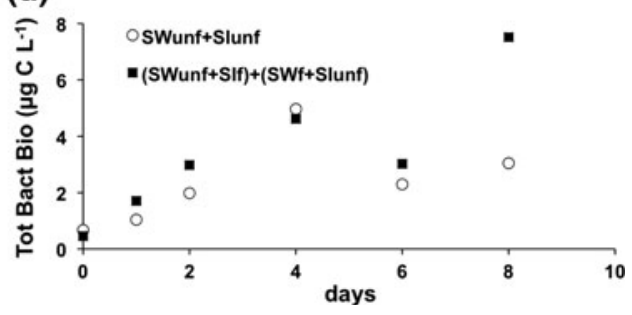

and $\mathbf{d}$ total bacterial biomass in the microcosms $\mathrm{SW}_{\mathrm{unf}}+\mathrm{SI}_{\mathrm{unf}}$ and $\left(\mathrm{SW}_{\mathrm{f}}+\mathrm{SI}_{\mathrm{unf}}\right)+\left(\mathrm{SW}_{\mathrm{unf}}+\mathrm{SI}_{\mathrm{f}}\right)$ for experiment B. This figure aims at estimating the level of competition between ice-derived and planktonic microorganisms 
Fig. 6 Fluxes of a salts, b dissolved organic carbon (DOC), $\mathbf{c}$ total dissolvable iron (Fe) and $\mathbf{d}$ particulate organic carbon (POC) during the melting experiment. We observe a decoupling between the release of DOC and POC

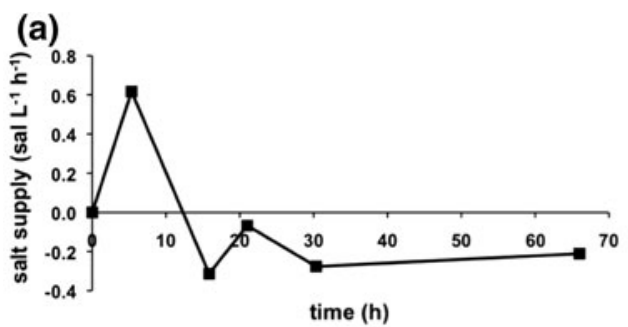

(c)

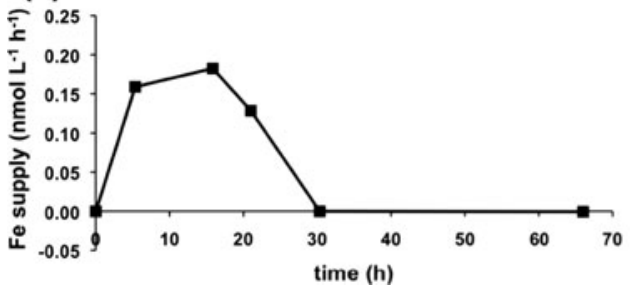

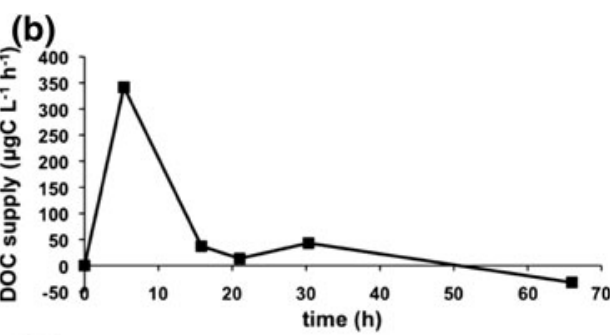

(d)

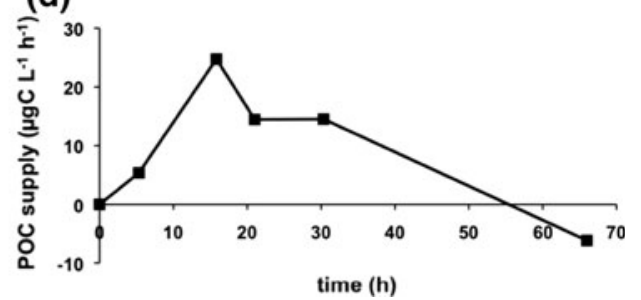

Sequential melting

In order to magnify the release of the sea ice constituents, we melted a 20 -cm-thick section of brown ice ( $14 \mathrm{~cm}$ diameter) in 13.5 L of seawater (sea ice to seawater volume ratio $\approx 1: 10$ corresponds to about $1 \mathrm{~m}$ thick ice cover melting in $10 \mathrm{~m}$ deep seawater). Depending on the sea ice thickness and the depth of the mixed layer, this ratio may vary widely in the field. In situ DOC, POC and TDFe concentrations may also vary in space and time. It is therefore important to note that while the fluxes presented here are adequately used to compare the timing of release of the sea ice constituents, the actual numbers are not representative of the in situ fluxes.

Figure 6 shows a supply in salts after $5 \mathrm{~h}$, due to gravitydriven brine drainage (brine salinity $>$ seawater salinity). This was followed by a supply of fresher water due to the melting of the ice matrix itself, less saline than seawater. We observe a decoupling between the release of dissolved and particulate organic matter. Maximal flux was reached after $5 \mathrm{~h}$ for DOC, but after $15 \mathrm{~h}$ for POC. After $20 \mathrm{~h}$, the fluxes of organic matter decreased strongly. DOC flux even became negative, indicating a quicker degradation of DOC in the reactor than in the control bottle. TDFe supply was maximal between 5 and $15 \mathrm{~h}$ $\left(0.18 \mathrm{nmol} \mathrm{L}{ }^{-1} \mathrm{~h}^{-1}\right)$. Nil Fe flux is reached after $30 \mathrm{~h}$ of melting.

\section{Discussion}

In situ distribution of microbial communities

A decrease of $\mathrm{Fe}$ and organic carbon concentrations in sea ice was observed (Table 2). Sea ice biomass did not seem to increase between the 29 November and 30 December despite improving conditions of temperature, light and brine volume fraction (Table 2). Krembs et al. (2001) and
Becquevort et al. (2009) pointed that algal development in sea ice might be controlled by space availability: i.e. algal growth is favoured when brine volume fractions $>8 \%$, roughly corresponding to ice temperature $>-4{ }^{\circ} \mathrm{C}$. Because the brine volume fraction is relatively high throughout this survey, the stagnation of the algal stock may be due to nutrient limitation. Loss of organic matter during ice melting and/or grazing pressure can also play a role as suggested by the high biomass of heterotrophic dinoflagellates measured in bottom ice on 30 December.

The distribution of algal species varied along the cores collected during ISPOL; however, seasonal variability was low during our time series (Fig. 2). Although their relative dominance varied, some algal species present in sea ice were also found in seawater, indicating a seeding from sea ice. For example, the in situ $30 \mathrm{~m}$ deep seawater showed an increase with time of the pennate diatoms biomass, which is the main algal group observed in bottom sea ice (Fig. 2). Phaeocystis sp. and flagellates seem to also develop in seawater. Such parallel between sea ice and seawater algal communities has already been observed in numerous studies and formed the basis of the seeding hypothesis (Garrison and Buck 1985; Smith and Nelson 1986; Garrison et al. 1987).

Fate of ice constituents during and after sea ice melting

\section{Autotrophs}

The Chla increase in the microcosm $\mathrm{SW}_{\mathrm{f}}+\mathrm{SI}_{\mathrm{unf}}$ confirms that at least a fraction of the sea ice community can grow in seawater (Fig. 4). This confirms results reported in Kuosa et al. (1992), although the increase in algal biomass in our trace-metal clean study was less important than in Kuosa's study. The increase of autotrophic biomass in $\mathrm{SW}_{\mathrm{f}}+\mathrm{SI}_{\mathrm{unf}}$ was mainly attributable to species $<10 \mu \mathrm{m}$ (Fig. 4). The 
decrease of $>10 \mu \mathrm{m}$ algae can be due to the lower $\mathrm{Fe}$ concentrations experienced in seawater compared to sea ice (large cells have a higher $\mathrm{Fe}$ demand than small ones; Sunda and Huntsman 1995). Iron concentrations in our microcosms were relatively high, but can be limiting for large ice algae, which are accustomed to Fe concentrations up to 2 orders of magnitude higher than in seawater. In the sea ice environment, sedimentation processes may be particularly efficient because of the production of exopolysaccharides (EPS) by sea ice algae (Palmisano and Sullivan 1985a; Krembs et al. 2001). EPS can stimulate the formation of aggregates (Passow 2002) and export as observed in rolling tanks (Riebesell et al. 1991) and silicon isotope measurements (Fripiat et al. 2007). Our field data also showed that sea ice diatoms were not systematically prevailing in surface seawater, most likely because they were rapidly exported below the mixed layer or were grazed immediately (Fig. 1). In the natural environmental, the intensity of grazing by copepods, amphipods or krill can greatly influence the recycling of organic material and $\mathrm{Fe}$ in surface waters (Lizotte 2003; Thomas and Papadimitriou 2003; Tovar-Sanchez et al. 2007; Lannuzel et al. 2010). Heavily grazed blooms can retain more biogenic elements in the surface layer, whereas ungrazed diatoms tend to sink out (Smetacek and Nicol 2005). Faecal pellets from these organisms can, however, contribute to the export of $\mathrm{C}$ to the depths.

\section{Heterotrophs}

Table 3 shows that at the start of the experiments, pack ice supplied much less heterotrophs than autotrophs, with even lower bacterial biomass when sea ice was added to the microcosm (Table 3). Figure 4 shows an increase in the ice-derived bacterial biomass with time, while the bacterial cell volume decreased in the microcosm $\mathrm{SW}_{\mathrm{f}}+\mathrm{SI}_{\text {unf. }}$. This decrease in cell volumes can be attributed to a decrease in the concentration of labile substrates such as the DOC (Roszak and Colwell 1987; Berman et al. 1994) or sizeselective grazing by protozoa (Gonzales et al. 1990). This latter scenario is supported by the higher protozoa biomass where the highest decrease in the bacterial biovolume is observed at the end of the experiment. Grazing by protozoa is also most probably responsible for the lower initial biomasses of phytoplankton and bacteria in the microcosms (Table 2) than in situ (Fig. 4). The effect of seeding on bacteria is poorly documented. Phylogenetic studies showed that sea ice bacterial population is similar to the seawater community (Bowman et al. 1997), metabolically active (Brinkmeyer et al. 2003) and that psychrophilic species were preferentially present in sea ice (Delille 1992; Helmke and Weyland 1995). Kaartokallio et al. (2005) reported that, in Baltic sea ice, ice-derived bacterial communities were able to adapt to salinity changes while under-ice bacterial assemblages seemed to suffer from osmotic stress. Physiological and community structure changes in response to a changing environment (e.g. salinity) will occur during the melting of sea ice (Kaartokallio et al. 2005).

\section{Organic matter and Fe}

Similar to other Antarctic pack ice field studies (e.g. Lannuzel et al. 2007; Becquevort et al. 2009; van de Merwe et al. 2011a, b), large accumulation in sea ice of both organic matter and $\mathrm{Fe}$ was reported during the ISPOL survey (Table 2; Arrigo and Thomas 2004; Lannuzel et al. 2008; Dumont et al. 2009), indicating that sea ice can be a significant source of organic matter and $\mathrm{Fe}$ to the phytoplankton-poor and Fe-starved Antarctic surface waters. Dissolved organic matter can originate from melting sea ice but also from excretion by phytoplankton, sea ice algal cell lysis, exudation or sloppy feeding by zooplankton (Kähler et al. 1997). The release of Fe from melting sea ice has been addressed by several authors (e.g. Sedwick and DiTullio 1997) and quantified in many studies (Lannuzel et al. 2007; 2008; 2010; van der Merwe et al. 2011a, b). In the Fe-limited Antarctic waters, this seasonal pulse of nutrients can trigger phytoplankton blooms, as confirmed during the ISPOL time series, our microcosms experiments and spring/summer satellite imagery of the marginal ice zone. Figure 4 shows that autotrophic and bacterial biomasses are stimulated in the microcosm amended with filtered sea ice. Algal growth can be triggered by (1) the supply of micronutrients such as Fe, (2) less grazing pressure (Giesenhagen et al. 1999) and (3) the stimulation of heterotrophic processes through the release of labile sea ice-derived DOM (Brandini and Baumann 1997), which will supply essential molecules for the autotrophs (e.g. siderophores or cytokines). In HNLC waters, carbon seemed to be the first limiting factor for bacterial growth, although $\mathrm{Fe}$ can quickly become limiting when carbon limitation is alleviated (Church et al. 2000; Kirchman et al. 2000; Becquevort et al. 2007). We note that the effect of melting sea ice is also observed between microcosms A and $\mathrm{B}$, with higher bacterial and algal biomasses in $\mathrm{B}$ (Table 3). Field data confirmed that sea ice melting was well underway when arriving on site on the 29 November, releasing $70 \%$ of $\mathrm{Fe}$ in surface seawater within the first 10 days of the time series (Lannuzel et al. 2008). Our microcosms samples were collected after this initial $\mathrm{Fe}$ fertilization. Therefore, the $1 \%$ sea ice inoculation would have only contributed to an increase of $4-5 \%$ of the initial seawater concentration of $\mathrm{Fe}$ in the microcosms $\mathrm{A}$ and $\mathrm{B}$. Note that the $\mathrm{Fe}$ concentrations in seawater were already relatively high (i.e. non-limiting for phytoplankton growth) 
compared to ice-free waters (typically $0.1-0.2 \mathrm{nmol} \mathrm{L}^{-1}$ ), particularly at the start of experiment $\mathrm{B}$ (Table 2). We come to the conclusion that the direct supply of Fe from sea ice represents an addition of only $4-5 \%$ of the initial concentrations of $\mathrm{Fe}$ in the microcosms. The contribution of ice-derived $\mathrm{Fe}$ is therefore not significant this late in the melting season. Instead, we believe that ice-derived DOM stimulated the bacterial and algal growths observed in the microcosm $\mathrm{SW}_{\mathrm{unf}}+\mathrm{SI}_{\mathrm{f}}$.

\section{Sequential melting}

In our microcosm experiments, all the sea ice constituents (microorganisms, DOM and $\mathrm{Fe}$ ) were released simultaneously into the water column. Sea ice melting is, however, not an instantaneous but rather a sequential process; the release of the sea ice constituents relies on the brine movement within the ice and at the ice-water interface (i.e. drainage, convection and diffusion processes). The main question is in which order organic and inorganic elements embedded in the gel-matrix in sea ice are released in seawater. Iron could well be released with the dense brines and rapidly exported towards deeper waters, and therefore not available for phytoplankton uptake. If $\mathrm{Fe}$ is released before sea ice microorganisms, then this nutrient supply is not beneficial for the sea ice community anymore. But if the release of $\mathrm{Fe}$ is slow, then it could be maintained in the surface water owing to the enhanced stratification and therefore be used by water-based and sea ice-based microorganisms. Riebesell et al. (1991) observed the release of the ice algae before the complete melting of the ice sheet, hence before the stabilization of the mixed layer. The same was observed in the case of Fe during the ISPOL time series, where $70 \%$ of $\mathrm{Fe}$ was released while the sea ice cover was still present (Lannuzel et al. 2008).

In the laboratory-based sequential melting experiment, we observed a decoupling between DOC and POC. Brine drainage is the first process at work to release salts as well as DOC $(5 \mathrm{~h})$, while POC was released at a later stage $(15 \mathrm{~h})$. As TDFe includes both the truly dissolved and particulate leachable fractions, dissolved $\mathrm{Fe}$ was released first together with DOC (maximum at $5 \mathrm{~h}$ ), while particulate leachable $\mathrm{Fe}$ was released with $\mathrm{POC}$ at a later stage (maximum at $15 \mathrm{~h}$ ). This decoupling between the dissolved and particulate Fe phase has been reported in the field (van der Merwe et al. 2011a). We note that some low-salinity water was released at the same time as the maximal fluxes of POC and particulate $\mathrm{Fe}$ (at $15 \mathrm{~h}$ ), possibly inducing a stabilization of the mixed layer before complete melting of sea ice is achieved (Fig. 6). This result also confirms field observations. We conclude that the 2-stage release of $\mathrm{Fe}$ favours both the sea ice- and seawater-based communities.
Several factors can increase the efficiency of the fertilization of the Antarctic surface waters: (1) the thinning of the mixed layer when freshwater is added also reduces the cellular $\mathrm{Fe}$ demand of pelagic algae required in light harvesting processes (Raven 1990); (2) $\mathrm{Fe}$ is released into seawater together with organic ligands, which increase the residence time of $\mathrm{Fe}$ in surface waters and therefore its bioavailability (van der Merwe et al. 2009; Hassler et al. 2011). The production of exopolysaccharides (EPS) by sea ice algae, however, stimulates the formation of aggregates and therefore lead to rapid sedimentation of ice-derived $\mathrm{Fe}$ (Riebesell et al. 1991; Meiners et al. 2004); and (3) heterotrophic activity in seawater favours the remineralization of $\mathrm{Fe}$ associated with ice-derived organic matter.

\section{Conclusion}

This paper presents the first results on microcosms experiments performed under trace-metal clean conditions. Our main findings are as follows: (1) pack ice supplies much less heterotrophs than autotrophs, (2) small ice algae $(<10 \mu \mathrm{m})$ and ice bacteria can grow in seawater, (3) planktonic algal and bacterial growths are stimulated by ice-derived DOM, (4) the contribution of Fe from melting sea ice is not significant in our microcosms experiments because most of the $\mathrm{Fe}$ was already released before our arrival on site and (5) dissolved and particulate sea ice constituents are released sequentially favouring both the sea ice- and seawater-based communities. Future studies should include the impact of grazing by zooplankton and sedimentation processes on the $\mathrm{Fe}$ and carbon cycling in the marginal ice zone. Additional work should also focus on the bio-availability of $\mathrm{Fe}$ in the sea ice environment, with special emphasis on size partitioning (soluble, dissolved and particulate), organic speciation and redox state $\left(\mathrm{Fe}^{2+}\right.$ and $\left.\mathrm{Fe}^{3+}\right)$ of $\mathrm{Fe}$.

Acknowledgments The authors are grateful to the officers and crews of the RV Polarstern for their logistic assistance during the ISPOL cruise. We would like to thank the Alfred Wegener Institute, especially Michael Spindler, David Thomas and Gerhard Dieckmann for allowing us to take part in the ISPOL cruise. This work was carried out in the framework of the Belgian research programme Action de Recherche Concertée "Sea Ice Biogeochemistry in a CLIMate change perspective" financed by the Belgian French Community under contract $n^{\circ}$ ARC-02/7-318287. This is also a contribution to the European Network of Excellence EUR-OCEANS (contract $n^{\circ} 511106-2$ ) and to the BELCANTO (contracts SD/CA/ 03A\&B) and BIGSOUTH (contract $\mathrm{N}^{\circ} \mathrm{SD} / \mathrm{CA} / 05 \mathrm{~A}$ ) projects financed by the Belgian Federal Science Policy Office. The present study is a Belgian input to the Surface Ocean Low Atmosphere Study international research initiative. Isabelle Dumont was supported by a Fonds pour la Recherche en Industries Agronomiques grant. Bruno Delille is a F.R.S-FNRS Research Associate. 
Open Access This article is distributed under the terms of the Creative Commons Attribution License which permits any use, distribution, and reproduction in any medium, provided the original author(s) and the source are credited.

\section{References}

Arrigo KR, Thomas DN (2004) Large scale importance of biology in the Southern Ocean. Antarct Sci 16(4):471-486

Arrigo KR, Mock T, Lizotte MP (2010) Primary producers and sea ice. In: Thomas DN, Dieckmann GS (eds) Sea ice. Blackwell Sci, Oxford, UK, pp 283-326

Becquevort S, Lancelot C, Schoemann V (2007) The role of iron in the bacterial degradation of organic matter derived from Phaeocystis antarctica. Biogeochemistry 83:119-135

Becquevort S, Dumont I, Tison J-L, Lannuzel D, Sauvée M-L, Chou L, Schoemann V (2009) Biogeochemistry and microbial community composition in sea ice and underlying seawater off East Antarctica during early spring. Polar Biol 32:879-895

Berman T, Hoppe HG, Gocke K (1994) Response of aquatic bacterialpopulations to substrate enrichment. Mar Ecol Prog Ser 104:173-184

Bowman JP, McCammon SA, Brown MV, Nichols DS, McMeekin TA (1997) Diversity and association of psychrophilic bacteria in Antarctic sea ice. Appl Environ Microbiol 63:3068-3078

Brandini FP, Baumann MEM (1997) The potential role of melted "brown ice" as sources of chelators and ammonia to the surface waters of the Weddell Sea, Antarctica (18th Symposium on Polar Biology). Proceedings of the NIPR symposium on polar biology 10:1-13

Brinkmeyer R, Knittel K, Jurgens J, Weyland H, Amann R, Helmke E (2003) Diversity and structure of bacterial communities in arctic versus antarctic pack ice. Appl Environ Microbiol 69:6610-6619

Church MJ, Hutchins DA, Ducklow HW (2000) Limitation of bacterial growth by dissolved organic matter and iron in the Southern Ocean. Appl Environ Microbiol 66:455-466

Cox GFN, Weeks WF (1988) Numerical simulations of the profile properties of undeformed first-year sea ice during the growth season. J Geophys Res 93(C10):12449-12460

de Jong J, Schoemann V, Tison J-L, Lannuzel D, Mattielli N (2008) High-accuracy determination of iron in seawater by isotope dilution multiple collector inductively coupled plasma mass spectrometry (ID-MC-ICP-MS) using nitrilotriacetic acid chelating resin for pre-concentration and matrix separation. Anal Chim Acta 623:126-139

Delille D (1992) Marine bacterioplankton at the Weddell Sea ice edge, distribution of psychrophilic and psychrotrophic populations. Polar Biol 12:205-210

Dumont I, Schoemann V, Lannuzel D, Chou L, Tison JL, Becquevort S (2009) Distribution and characterization of dissolved and particulate organic matter in Antarctic pack ice. Polar Biol 32(5):733-750

Eicken H (2003) From the microscopic, to the macroscopic, to the regional scale: growth, microstructure, and properties of sea ice. In: Thomas DN, Dieckmann GS (eds) Sea ice-an introduction to its physics, chemistry, biology and geology. Blackwell Science, Oxford, pp 22-83

Fripiat F, Cardinal D, Tison JL, Worby A, Andre L (2007) Diatominduced silicon isotopic fractionation in Antarctic sea ice. J Geophys Res-Biogeosci 112:G02001

Garrison DL, Buck KR (1985) Sea-ice algal communities in the Weddell Sea: species composition in ice and plankton assemblages. In: Gray JS, Christiansen ME (eds) Marine biology of polar regions and effects of stress on marine organisms. J Wiley, New york, pp 103-122
Garrison D, Buck KR, Fryxell GA (1987) Algal assemblages in Antarctic pack ice and in-edge plankton. J Phycol 23:564-572

Giesenhagen HC, Detmer AE, de Wall J, Weber A, Gradinger RR, Jochem FJ (1999) How are Antarctic planktonic microbial food webs and algal blooms affected by melting of sea ice? Microcosm simulations. Aquat Microb Ecol 20:183-201

Golden KM, Ackley SF, Lytle VI (1998) The percolation phase transition in sea ice. Science 282:2238-2241

Gonzalez JM, Iriberri J, Egea L, Barcina I (1990) Differential rates of digestion of bacteria by fresh-water and marine phagotrophic protozoa. Appl Environ Microbiol 56:1851-1857

Gradinger R, Ikävalko J (1998) Organism incorporation into newly forming Arctic sea ice in the Greenland Sea. J Plankton Res 20:871-886

Hassler CS, Schoemann V, Mancuso-Nichols C, Butler ECV, Boyd PW (2011) Saccharides enhance iron bioavailability to Southern Ocean phytoplankton. Proc Natl Acad Sci 108:1076-1081

Hellmer HH, Schroder M, Haas C, Dieckmann GS, Spindler M (2008) The ISPOL drift experiment. Deep-Sea Res II(55):913-917

Helmke E, Weyland H (1995) Bacteria in sea-ice and underlying water of the eastern Weddell Sea in midwinter. Mar Ecol Prog Ser 117:269-287

Hillebrand H, Dürselen C-D, Kirschtel D, Pollingher U, Zohary T (1999) Biovolume calculation for pelagic and benthic microalgae. J Phycol 35:403-424

Kaartokallio H, Laamanen M, Sivonen K (2005) Responses of Baltic Sea ice and open-water natural bacterial communities to salinity change. Appl Environ Microbiol 71:4364-4371

Kahler P, Bjornsen PK, Lochte K, Antia A (1997) Dissolved organic matter and its utilization by bacteria during spring in the Southern Ocean. Deep-Sea Res II 44:341-353

Kirchman DL, Meon B, Cottrell MT, Hutchins DA, Weeks D, Bruland KW (2000) Carbon versus iron limitation of bacterial growth in the California upwelling regime. Limnol Oceanogr 45:1681-1688

Krembs C, Mock T, Gradinger R (2001) A mesocosm study of physical-biological interactions in artificial sea ice: effects of brine channel surface evolution and brine movement on algal biomass. Polar Biol 24:356-364

Kuosa H, Norrman B, Kivi K, Brandini F (1992) Effects of Antarctic sea ice biota on seeding as studied in aquarium experiments. Polar Biol 12:333-339

Lancelot C, Mathot S, Veth C, de Baar H (1993) Factors controlling phytoplankton ice-edge blooms in the marginal ice-zone of the Northwestern Weddell Sea during sea-ice retreat 1988-field observations and mathematical-modeling. Polar Biol 13:377-387

Lancelot C, de Montety A, Goosse H, Becquevort S, Schoemann V, Pasquer B, Vancoppenolle M (2009) Spatial distribution of the iron supply to phytoplankton in the Southern Ocean: a model study. Biogeosci Discuss 6:4919-4962

Lannuzel D, de Jong J, Schoemann V, Trevena A, Tison JL, Chou L (2006) Development of a sampling and flow injection analysis technique for iron determination in the sea ice environment. Anal Chim Acta 556:476-483

Lannuzel D, Schoemann V, de Jong J, Tison JL, Chou L (2007) Distribution and biogeochemical behaviour of iron in the East Antarctic sea ice. Mar Chem 106:18-32

Lannuzel D, Schoemann V, de Jong J, Chou L, Delille B, Becquevort S, Tison JL (2008) Iron study during a time series in the western Weddell pack ice. Mar Chem 108:85-95

Lannuzel D, Schoemann V, Pasquer B, van der Merwe P, Bowie AR (2010) What controls the distribution of dissolved iron in the seasonal ice zone? Spatial, seasonal and inter-annual variability. J Geophys Res 115:G03022. doi:10.1029/2009JG001031

Lizotte MP (2003) The microbiology of sea ice. In: Thomas DN, Dieckmann GS (eds) Sea ice-an introduction to its physics, 
chemistry, biology and geology. Blackwell Science Ltd, Oxford, pp 184-210

Martin JH, Fitzwater SE, Gordon RM (1990) Iron deficiency limits phytoplankton growth in Antarctic waters. Global Biogeochem Cycles 4(1): 5-12, 10

Mathot S, Becquevort S, Lancelot C (1991) Microbial communities from the sea ice and adjacent water column at the time of ice melting in the northwestern part of the Weddell Sea. Polar Res $10: 267-275$

Meiners K, Brinkmeyer R, Granskog MA, Lindfors A (2004) Abundance, size distribution and bacterial colonization of exopolymer particles in Antarctic sea ice (Bellingshausen Sea). Aquat Microb Ecol 35(3):283-296

Menden-Deuer S, Lessard EJ (2000) Carbon to volume relationships for dinoflagellates, diatoms, and other protist plankton. Limnol Oceanogr 45:569-579

Palmisano AC, Sullivan CW (1985) Pathways of photosynthetic carbon assimilation in sea-ice microalgae from McMurdo Sound, Antarctica. Limnol Oceanogr 30:674-678

Passow U (2002) Transparent exopolymer particles (TEP) in aquatic environments. Prog Oceanogr 55:287-333

Porter KG, Feig YS (1980) The use of DAPI for identifying and counting aquatic microflora. Limnol Oceanogr 25:943-948

Raven JA (1990) Predictions of $\mathrm{Mn}$ and $\mathrm{Fe}$ use efficiencies of phototrophic growth as a function of light availability for growth and of $\mathrm{C}$ assimilation pathway. New Phytol 116:1-18

Riebesell U, Schloss I, Smetacek V (1991) Aggregation of algae released from melting sea ice-implications for seeding and sedimentation. Polar Biol 11:239-248

Roszak DB, Colwell RR (1987) Survival strategies of bacteria in the natural environment. Microbiol Rev 51:365-379

Różańska M, Poulin M, Gosselin M (2008) Protist entrapment in newly formed sea ice in the Coastal Arctic Ocean. J Mar Syst 74:887-901

Schlitzer R (2008) Ocean data view, http://odv.awi.de

Sedwick PN, DiTullio GR (1997) Regulation of algal blooms in Antarctic shelf waters by the release of iron from melting sea ice. Geophys Res Lett 24:2515-2518

Simon M, Azam F (1989) Protein-content and protein-synthesis rates of planktonic marine-bacteria. Mar Ecol Prog Ser 51:201-213

Smetacek V, Nicol S (2005) Polar ocean ecosystems in a changing world. Nature 437:362-368
Smith WO, Nelson DM (1986) Importance of ice edge phytoplankton blooms in the Southern Ocean. Bioscience 36:251-257

Sugimura Y, Suzuki Y (1988) A high-temperature catalytic-oxidation method for the determination of non-volatile dissolved organiccarbon in seawater by direct injection of a liquid sample. Mar Chem 24:105-131

Sunda WG, Huntsman SA (1995) Iron uptake and growth limitation in oceanic and coastal phytoplankton in seawater. Mar Chem 50:189-206

Thomas DN, Papadimitriou S (2003) Biogeochemistry of sea ice. In: Thomas DN, Dieckmann GS (eds) Sea ice-an introduction to its physics, chemistry, biology and geology. Blackwell Science Ltd, Oxford, pp 267-302

Tison JL, Worby A, Delille B, Brabant F, Papadimitriou S, Thomas D, de Jong J, Lannuzel D, Haas C (2008) Temporal evolution of decaying summer first-year sea ice in the Western Weddell Sea, Antarctica. Deep Sea Res II 55:975-987

Tovar-Sánchez A, Duarte CM, Hernández-León S, Sañudo-Wilhelmy SA (2007) Krill as a central node for iron cycling in the Southern Ocean. Geophys Res Lett 34:L11601

Utermölh H (1958) Zur Vervelkommnung der quantitativen Phytoplankton-Methodik. Mitt Int Verein Theor Angew Limnol 9:1-38

van der Merwe P, Lannuzel D, Mancuso Nichols CA, Meiners K, Heil P, Norman L, Thomas D, Bowie AR (2009) Biogeochemical observations during the winter-spring transition in East Antarctic sea ice: implications of exopolysaccharides. Mar Chem 15(3-4):163-175

van der Merwe P, Lannuzel D, Mancuso Nichols CA, Meiners K, Bowie AR (2011a) Iron fractionation in pack and fast ice in East Antarctica: potential for temporal decoupling between the release of dissolved and particulate iron during spring melt. Deep Sea Res II 58(9-10):1222-1236

van der Merwe P, Lannuzel D, Bowie AR, Meiners KM (2011b) High temporal resolution observations of spring fas ice melt and seawater iron enrichment in East Antarctica. J Geophys Res 116:G03017. doi:10.1029/2010JG001628

Watson SW, Novitsky TJ, Quinby HL, Valois FW (1977) Determination of bacterial number and biomass in the marine environment. Appl Environ Microbiol 33:940-946

Yentsch CS, Menzel DW (1963) A method for the determination of phytoplankton chlorophyll and phaeophytin by fluorescence. Deep Sea Res Oceanogr Abstr 10(3):221-231 